\title{
Acción surrealista y medios de intervención. El surrealismo en las revistas, 1919 - 1929
}

\author{
Javier MaÑERo Rodicio \\ CES Felipe II, Universidad Complutense de Madrid
}

Artículo recibido: 1-4-2012 / Aceptado: 8-6-2012

Resumen: Las revistas son elementos imprescindibles del complejo entramado surrealista. Aun siendo hoy perfectamente conocidas y ampliamente utilizadas en los estudios sobre aquel movimiento, caben todavía, muy particularmente en lengua española, análisis centrados específicamente en el conjunto de aquellas publicaciones. Tal es el objetivo del presente estudio, aplicado a establecer un relato articulado del devenir del surrealismo, siempre al hilo de los avatares editoriales y la descripción detallada de sus revistas. En esta su primera entrega se aborda la década en que el surrealismo, inserto en el ambiente dadaísta, se forma alrededor de la revista Littérature y madura en La Révolution surréaliste. El conflictivo Segundo manifiesto del surrealismo cierra este período en 1929.

Palabras clave: Surrealismo, Dadaísmo, Revistas de arte, Manifiestos, Dada, Littérature, La Révolution surréaliste, Variétés.

AвSTRACT: Magazines are an indispensable part of the complex Surrealist framework. Despite being very wellknown today, there is still a need -in spanish language at least - for interconnecting and comprehensive accounts of Surrealistic activity specifically undertaken by the publishing enterprises of periodical publications. This is the objective of this particular study which, in this first instalment, deals with the decade in which Surrealism, from within the realms of Dadaism, begins to take shape around the magazine called Littérature and then comes of age in La Révolution surréaliste. The conflictive Second Manifesto of Surrealism brings this period to an end in 1929.

Keywords: Surrealism, Dadaism, Art Magazines, Surrealist Manifestos, Dada, Littérature, La Révolution surréaliste, Variétés.

\section{EL PUNTO DE VISTA DE LAS REVIS- TAS}

En las frecuentes revisiones actuales del surrealismo suele destacarse más el carácter colectivo de su activismo estéticopolítico que los logros artísticos específicos en los que la tradición del Modernisme se fijó preferentemente. Con tal fin, se ha vuelto una y otra vez al enorme volumen documental que aquel Dadá y posterior Surrealismo dejó de su inagotable acción: testimonios, correspondencia, proclamas, arte, publicaciones; materiales todos ellos disponibles, pues el surrealismo es una "tradición" nunca interrumpida. Entre las publicaciones del su- 
rrealismo histórico, las periódicas constituyen una fuente especialmente propicia para revisitar en su propio contexto colectivo -el único adecuado al surrealismo- las ideas y actividades de aquellos grupos. A través de sus revistas se accede en tiempo real a las propuestas y los debates ideológicos o artísticos, pues no hubo momento alguno en la vida de las diversas facciones vinculables al surrealismo que no tuviera su debida ilustración periódica. Aunque la aproximación a la época a través de estos medios es común, se echan de menos, y muy particularmente en la bibliografía española, aproximaciones de conjunto centradas específicamente en las publicaciones periódicas del movimiento y en su descripción. A tal objetivo se aplica este estudio, un relato del devenir del surrealismo, de sus variables redes humanas, ideológicas y estéticas, establecido, precisamente, desde los avatares editoriales de sus publicaciones periódicas, auténticas protagonistas del presente texto y de sus imágenes.

Estos contenidos se van a circunscribir aquí al análisis de las publicaciones en lengua francesa, propias o bien puntualmente asociadas al grupo aglutinado por André Breton, desde su embrión dadaísta de 1919 hasta la crisis de 1929, la etapa de mayor efervescencia colectiva. A través de ellas surgirá, además, un esquema de sus relaciones con otros colectivos y las revistas que promovían. Por otra parte, la progresiva presencia de la imagen y de las artes visuales en las revistas del Dadá-surrealismo parisino será objeto de una especial atención.

\section{LA PUBLICACIÓN SURREALISTA Y SUS OBJETIVOS}

André Breton concebía la publicación surrealista como un "medio de intervención", lo que indica hasta qué punto el órgano periódico del grupo fue siempre considerado elemento central de su acción ${ }^{1}$. A

\footnotetext{
1 Breton reflexiona acerca de esto ya en los años 60: "Las revistas, para nosotros, han constituido siempre un medio de contacto proporcionado a las expectativas
}

diferencia de la acción nihilista aislada y ajena a planificaciones del dadaísmo, el medio surrealista se orientó a la desactivación sistemática y socialmente comprometida del establecimiento cultural y moral, proyectando su actividad preferentemente desde la literatura y el arte, pero también desde la ciencia, el debate social o el pronunciamiento político expreso. Al reparar en sus publicaciones periódicas hay que destacar, en primer lugar, una función fundamental como órgano grupal orientado a la difusión de su acción tanto común como individual, de sus juegos, encuestas, proclamas o procesos. También, sin duda, de las participaciones literarias y artísticas individuales, así como de su teoría política y estética. En ellas cupo toda dispersión temática y estratégica, con predominios más literarios, políticos, etnográficos o artísticos dependiendo del momento del grupo y del carácter de cada proyecto editorial. Pero lo que siempre se constata es cómo la historia de las revistas del surrealismo se desarrolla in crescendo tanto en la creciente confianza depositada en este medio difusor y agitador de ideas, como en la ambición editorial de cada nuevo proyecto. Tal ambición se manifiesta, muy particularmente, en la aproximación título tras título a lo visual y al arte, en correspondencia con los intereses mostrados por sus propios directores y animadores, así como a un peso cada vez mayor de los artistas en el grupo. Dicho esto, conviene de inmediato señalar que la publicación periódica surrealista en ningún caso puede con propiedad calificarse como revista de arte, un formato este ya perfectamente establecido en la época al que nunca quiso ajustarse por completo, ni siquiera cuándo la importancia del arte en sus páginas se hizo determinante.

El arte en ellas nunca aparece como objeto de crítica estética, sino como un modo afirmativo de lo "real maravilloso" que entra a formar parte de esa obra global que cons-

diversas y cambiantes de ese público indefinido que nos corresponde. Nos aportan un ritmo de respiración ajustado al mismo tiempo a nuestras necesidades vitales y a la naturaleza del aire ambiente." Rev. surrealista La Brèche, no 1, París, octubre 1961. 
tituye siempre el propio medio surrealista, sea este revista, exposición, o cualquier otra manifestación pública del grupo. Y lo hace con la misma presencia acrítica -en el sentido de afirmativa y orientada a la acción- que los poemas, proclamas, textos, estudios científicos, reseñas de prensa e imágenes dispares -artísticas o no- que convierten la revista en dossier de realidades inesperadas que se devuelven al mundo para transformarlo. Cuando en los medios surrealistas aparecen reflexiones sobre las producciones artísticas propias, suelen versar sobre su ubicación cultural y nunca sobre sus propias condiciones formales específicas. En ese sentido, su actitud tiene un carácter contextual y crítico relativo al propio encaje de las actividades surrealistas en el tejido social para, por ejemplo, ponerse "al servicio de la revolución" marxista-leninista, o bien, en lo artístico, para descubrir en la obra de artistas ajenos al grupo los mismos resortes que determinan su acción -es, por ejemplo, el caso de Picasso, Paul Klee o el primer De Chirico. Mientras la crítica de arte de la época, incluida la más avanzada, presupone respecto al objeto artístico una respetuosa y distanciada contemplación estéticamente determinada, la acción surrealista, poema, pintura u objeto, es un mecanismo desencadenante o no es. Así, la re-creación o descubrimiento automatista, el "funcionalismo" simbólico, las paradojas visuales/textuales, las metodologías paranoico-críticas y otras variantes de la prospección surrealista, no admiten otro juicio que el derivado de su mayor o menor perfección y eficiencia como tales mecanismos, su capacidad para recuperar/otorgar un sentido inusitado de lo real, reubicando así la sensibilidad y ampliando las maneras del estar en el mundo.

Los medios surrealistas desprecian la belleza burguesa encumbrada desde la institución y la crítica profesional. Cuando, una vez moderadas las acciones tipográficas dadaístas, hubo que buscar modelos para las publicaciones, se hallaron, como veremos, en la precisión científica antes que en territorios establecidos del arte. Pero tal elección para sus publicaciones no deja ser el correlato de una fascinación generalizada por la ciencia experimental, esta es, antes que cualquier consideración derivada de la idea estética, su modelo y ejemplo de aproximación al mundo. Precisión en el análisis de los datos del espíritu, de los datos primarios. Por lo tanto, las técnicas artístico/poéticas puestas a punto para sortear la barrera cultural y racional que oculta aquellos datos, son otros tantos diseños de experiencias de laboratorio orientados a la mayor efectividad y precisión posibles en el sentido marcado por cada prospección. El artefacto artístico surrealista es así siempre diferente y la escuela no tiene marca estilística alguna, pues no fueron los problemas de la plástica los que lo generaron. Su perfección y también su belleza tienen, por lo tanto, más en común con el experimento bien concebido o el efectivo modelo científico que abre otras ventanas al mundo, que con las armonías y equilibrios eurítmicos.

En un orden más social, habría también que identificar como una característica básica del surrealismo histórico y de sus medios una clara vocación propagandística $\mathrm{y}$, andando los años, internacional. En la entrada Revues surréalistes del Dictionnaire abrégé du surréalisme se cita con orgullo la dimensión alcanzada por la difusión del movimiento, además de hacer un relato escueto pero muy completo de las cabeceras propias o asociadas puntualmente al grupo bretoniano que es necesario tener aquí en cuenta². La

\footnotetext{
2 "Revistas surrealistas: La revista Littérature (33 números, de 1919 a 1924) puede ser considerada como primera revista surrealista. Desde sus inicios, publicó en efecto las Poésies de Isidore Ducasse y Les Champs magnétiques de Breton y Soupault. La parte que dedica a Dadá está constantemente compensada por un espíritu de investigación, por una preocupación moral ajena a aquél. Con La Révolution surréaliste (12 números, de 1924 a 1929) y Le Surréalisme au service de la Révolution (6 números, 1930-1933), 'la actividad surrealista, que desempeña -escribe Georges Hugnet-, en el plano poético, un papel temporal y absoluto de primer nivel, adopta en conjunto una actitud antiburguesa y antiliteraria cuando menos subversiva, fuertemente agresiva $y$, en verdad, revolucionaria... A favor o en contra del surrea-
} 
mayor parte de las cabeceras allí citadas forman parte del presente relato.

[Fig. 1 a, b] Noticias desde las revistas del arte moderno.- Presentados algunos aspectos distintivos de la publicación periódica del surrealismo, es posible ya introducirse en la maraña de cabeceras que desde 1919 dan forma pública al movimiento. Antes de iniciar un recorrido más ajustado a la cronología, tiene interés considerar algunos ejemplos de la visión que ya en los propios años de entreguerras se tuvo del fenómeno surrealista desde las revistas de arte. Citaré tres artículos especialmente relevantes por su valor documental y crítico, aunque sean hoy poco recordados, aparecidos en dos de las revistas de arte entonces más difundidas: Cahiers d'Art y L'Amour de l'Art. El primero de esos artículos aparece en otoño de 1926 en Cahiers d'Art, la recién estrenada revista de Christian Zervos ${ }^{3}$, y está firmado por Robert Desnos, poeta surrealista de primera línea

lismo, muchos espíritus han sido habituados por él a la idea de la revolución, arrastrados hacia ella por la costumbre a este estado de hecho donde verdaderamente les mantenía, tanto si lo querían como si no, la actividad surrealista.' Muchas revistas han dedicado números especiales al surrealismo: Le Disque vert (1925), Variétés (Bruselas, 1929), Les Cahiers du Sud (1929), This Quarter (1932), Spektrum (Suecia, 1933), L'Amour de l'art (marzo de 1934), Documents 34 (Bruselas, mayo y noviembre de 1934), Contemporary poetry and prose (Londres, junio de 1936) Cahiers d'Art (Números 5-6 de 1935 y 1-2 de 1936), etcétera. Tras haber estado abierta durante mucho tiempo a la colaboración de los surrealistas, la revista Minotaure se ha convertido en una revista surrealista. Publicaciones surrealistas en el extrajero: Surrealismus (Praga), Nadrealizam danas i ovde (Yugoeslavia), Gazeta de Arte (España), Konkretion (Dinamarca), L'Échange surréaliste (Japón), etcétera." (sin firma) En: A. BRETON y P. ÉLUARD, Diccionario abreviado del surrealismo (1938), Madrid, 2003. pp. 87-88.

${ }^{3}$ Cahiers d'Art fue la revista de arte más influyente de su época y adquirirá una gran relevancia para el surrealismo en los años 30. No existen reimpresiones. Sobre la publicación en general remito a un estudio propio: J. MAÑERO, "Christian Zervos y Cahiers d'Art. La invención del arte contemporáneo", Locus Amoenus, no 10, 2009-10, U. Autònoma de Barcelona, 2011. http:// ddd.uab.cat/pub/locus/11359722n10p279.pdf y hora. Bajo el título Surréalisme 4 escribe el que puede ser considerado primer gran artículo ilustrado centrado en las actividades artísticas surrealistas, presentando a algunos de sus artistas, la mayor parte de los cuales habían participado en la segunda exposición del grupo celebrada ese mes de marzo en la Galerie Surréaliste. Tras invocar el precedente de Picabia, Picasso y Duchamp, Desnos abunda en un debate fundamental para Breton y sus poetas, desarrollado por entonces en La Révolution surréaliste: "Se ha reprochado a menudo al surrealismo ser inaplicable a la pintura. El caso es que, en efecto, el gran problema de la pintura surrealista fue la aplicación de la definición del surrealismo a los procedimientos pictóricos. (...) El poeta surrealista se sirve de palabras conocidas y escribe con letras corrientes. El pintor puede pintar, en el sentido 'manual' la palabra a su antojo" ${ }^{\prime 2}$. Se comparte la inequívoca postura de Breton a favor del medio pictórico precisamente cuando, hacia 1926, muchos de los poetas del grupo eran ya conscientes del potencial de las imágenes, de su poderosa inmediatez, y se entregan a las prácticas visuales como el cadavre esquís o, algo más tarde, el objeto surrealista. Desnos saluda, pues, con entusiasmo en este texto la llegada de los pintores, de los "prospectores del sueño", incluyendo a los maestros ya surrealistas en su esencia, como Picasso o Picaba, así como también a los jóvenes que muy rápidamente se han integrado en las discusiones del grupo.

[Fig. 1 c] Los otros dos artículos antes indicados son muy posteriores y revisten sobre todo un interés historiográfico. La difundida revista $L^{\prime}$ Amour de l'Art ${ }^{6}$ no se caracteri-

4 R. DESNOS, «Surréalisme», Cahiers d'Art, no 8, 1926 (pp. 210-213, 9 ilust: Klee, Miro, Arp, Chirico, Ernst, Masson, Man Ray, Malkine, Tanguy)

${ }^{5}$ Ibid., p. 213

${ }^{6} \mathrm{~L}^{\prime}$ Amour de l'art. Art ancien, art moderne, architecture, arts appliqués. Revista de arte de modernidad moderada e interesada por los artistas de la Escuela de París. Editada en París con periodicidad mensual entre 1920 y 1951. Formato: 23,5 x 30,2 cm. Directores (redactores jefe) consecutivos hasta 1939: Louis Vauxcelles, Walde- 
zó por apuestas arriesgadas y las novedades surrealistas están prácticamente ausentes de sus páginas, sin embargo, la excepción es verdaderamente notable. Entre 1933 y 1934 su entonces director, el historiador René $\mathrm{Hu}-$ ygue, emprende un ambicioso proyecto para la revista, una Histoire de l'art contemporaine ${ }^{7}$ que irá apareciendo en ella cada mes durante dos años. La seriedad metodológica, el cuidado documental y la variedad e importancia de sus colaboradores en cada capítulo, hacen de este tempranísimo documento una primicia tan sorprendente como desconocida en la historiografía del arte del siglo xx. El capítulo dedicado por la revista al surrealismo así lo demuestra ${ }^{8}$. Tras una interesante introducción de Huygue, el cuerpo del capítulo está confiado a Jean Cassou, uno de los más destacados colaboradores de Cahiers d'Art, donde, sin embargo, nuca publicó los extraordinarios análisis que sobre Dadá y surrealismo ahora acomete. Sorprende la nitidez con la que ya en 1934 un crítico moderno, sin vínculo particular con el surrealismo ni sus medios, percibe la dimensión de la ruptura que supuso el surrealismo respecto a los principios estéticos anteriores: "Lo cierto es que este movimiento, sobre todo en su nacimiento con el cataclismo Dadá, rompía por completo con todas las nociones y todas las preocupaciones de la plástica. Las revoluciones precedentes, en su ruptura con el pasado inmediato, permanecían aún cautivas de la plástica. Tan solo retomaban la tradición de más lejos" ${ }^{\prime 9}$. Como se ve, el análisis de Dadá y del Surrealismo se hace inseparable como

mar George, François Fosca, René Huyghe. No existen reimpresiones.

${ }^{7}$ Pueden hallarse datos más precisos sobre esta temprana Historia del arte Contemporáneo en: J. MAÑRO, París 1919-1939. Escultura, crítica y revistas de arte, Madrid 2009, p. 31 y suc. http://eprints.ucm.es/8699/

8 "Histoire de l'art contemporaine, Capitulo XII, La nouvelle subjetivité" (pp. 313-342), L'Amour de l'Art, no 3, 1934, ocupa buena parte de un fascículo que, como puede comprobarse en la nota 2, fue tenido como un $\mathrm{n}^{\mathrm{o}}$ especial de L'Amour de l'Art dedicado el surrealismo.

9 J. CASSOU, "Le dadaïsme et le surréalisme", L'Amour de l'Art, no 3, marzo 1934, (pp. 337-340), p. 337. partes o momentos de un mismo proceso de ruptura. Según Cassou, el cubismo no habría supuesto, tal como es habitual pensar, la crisis definitiva de las tradiciones artísticas de occidente, sino, en realidad, una condensación más del tradicional análisis plástico de lo visual: la ruptura comenzó realmente cuando la plástica desaparece como motivo central del quehacer artístico con la salida de la historia del arte que supuso la "carcajada Dadá" y su fijación surrealista. Para reforzar sus afirmaciones, Cassou aduce a su artículo una clase de producción artística mucho más difícil de introducir en la historia de las categorías artísticas, se trata del ready-made y del objeto surrealista. Los objetos y su innata vocación subversiva respecto a los ideales de la cultura. Con su ser mundo -que no representación- y con el azar subconsciente que los elige y conforma, el juicio estético deja de ser desinteresado pues en ellos, afirma el crítico, la sangre y el sexo son intereses claros, revelaciones psicoanalíticas constantes de la búsqueda surrealista que tiran bajamente por tierra importantes ideales: "La autonomía del arte por la que se pagó tan alto precio, se desvanece" ${ }^{\prime 10}$. Pero la autonomía del arte era desde la Ilustración el gran proyecto estético de la modernidad y al fin, el mito del modernisme. Cassou se introduce con precisión filosófica y extraña anticipación en un debate de posmodernidad para el que habrá que esperar muchas décadas, situando a Dadá y surrealismo en su inicio, exactamente como, desde muy diversos frentes intelectuales, se hará a partir de 1970.

[Fig. 2] Queda un tercer artículo, como el anterior de 1934, aunque este aparecido en Cahiers d'Art, dedicado a valorar retrospectivamente las actividades del grupo parisino implicado en el Dadá y posterior Surrealismo. Se trata de Dada à Paris ${ }^{11}$ de Georges Hugnet, escritor y crítico de arte, este sí, vinculado al grupo bretoniano como uno de sus teóricos en los años 30, que culmina con este

\footnotetext{
${ }^{10}$ Ibid., p. 338

${ }^{11}$ G. HUGNET, “Dadá à Paris", Cahiers d'Art, no 1-4, 1934 (pp. 109-114, 12 ilust.)
} 
artículo una anterior serie de tres titulados genéricamente L'esprit Dada dans la peinture ${ }^{12}$, aparecidos a lo largo de 1932 en esa misma revista. Sírvanos su preciso relato para situar el origen del grupo surrealista, años antes del Manifeste du surréalisme, en el momento Dadá y con ello introducir las revistas de la primera etapa del grupo humano que dará lugar al surrealismo. Hugnet hace un pormenorizado recorrido por las actividades del Dadá parisino con constantes referencias a la revista Littérature, dejaremos que aquí y allá este desconocido relato -en su primera versión de Cahiers d'Art- ilustre nuestro recorrido por aquella revista perteneciente históricamente al entramado dadaísta, pero que Breton y su grupo siempre tuvieron por fundamentalmente surrealista ${ }^{13}$, pues, en efecto, el surrealismo se formó a su alrededor.

\section{DADÁ Y/O SURREALISMO EN PARÍS}

[Fig. 3] Las publicaciones del dadaísmo.- "Dadá hallará en París su apogeo poético y, mediante su muerte, su transformación y su plenitud. En París, Tzara conoce al grupo de Littérature, revista fundada en marzo de 1919, en la que había colaborado desde el $n^{0}$ 2, y dirigida por Aragon, Breton

${ }^{12}$ Esta serie de artículos apareció en los números de Cahiers d'Art: 1-2, 6-7 y 8-10 de 1932 y, junto a Dada à Paris, constituyen una completa y detallada historia de Dadá construida en buena parte desde sus revistas y eventos públicos. La perspectiva con que Hugnet percibe ya aquellos acontecimientos queda reflejada en el siguiente fragmento correspondiente al inicio de la serie: "Dadá no busca, pues, que ser subversivo y en 1916 lo subversivo es el modernismo: cubismo, futurismo, música negra, todo aquello que exaspera al mundo. Sin embargo Dadá no es moderno, y aun menos modernista, Dadá es actual y de ahí su actividad póstuma." G HUGNET, "L'esprit Dada dans la peinture I. Zurich \& New York", Cahiers d'Art, no 1-2, 1932 (pp. 57-65, 22 ilust.), p. 57.

${ }^{13}$ La cita del Diccionario abreviado del surrealismo consignada en la nota 3 confirma esta adscripción, aunque ciertamente retrospectiva, de Littérature al surrealismo pleno. Por otra parte, Breton defendió expresa y reiteradamente esta idea, como más abajo se comprobará. y Soupault"14. De tal modo concluye Hugnet el primero de sus artículos de 1932 sobre "El espíritu Dadá en la pintura". El Dadá más activo de París no habría sido el de Marcel Duchamp o incluso el de Francis Picabia, artistas muy independientes, dispuestos a participar en las actividades del dadaísmo pero no a integrarse plenamente en sus grupos, sino el surgido del encuentro entre Tristan Tzara, armado con su revista Dada, y los jóvenes promotores de otra publicación: Littérature, citados por Hugnet. Durante los años de la guerra, este mismo grupo de escritores había participado en experiencias editoriales relevantes como, muy especialmente, SIC (Sons, Idées, Coluleurs, Formes) (1916-1919) ${ }^{15}$, pequeña revista vanguardista fundada por Pierre Albert-Birot que anuncia el tono e incluso algunos recursos tipográficos después desarrollados por las publicaciones Dadá. También en Nort-Sud (1917-1918) ${ }^{16}$ donde, como en la anterior, compartieron páginas con Apollinaire, Pierre Reverdy o Max Jacob, es decir con los grandes valedores del cubismo. En el apartado documental correspondiente de la Histoire de l'art contemporaine de L'Amour de l'Art, Germain Bazin sitúa estas dos revistas de plena guerra como precedentes necesarios de Littérature: "Completamente impregnadas de cubismo y de futurismo, estas dos revistas presentaban ya un carácter subversivo, pero de un modo de alguna manera relativo, debido a sus tendencias

${ }^{14}$ G. HUGNET, “L'esprit Dada dans la peinture I. Zurich \& New York", Op. cit., p. 65.

15 SIC. Sons, Idées, Coluleurs, Formes. Revista literaria y artística de tono vanguardista. Editada en París, 54 números en 41 fascículos entre 1916 y 1919. Formato: 28 x 22,5 cm. Director Pierre Albert-Birot. Reimpresión: SIC, Jean-Michel Place, París, 1980 y Éditions de la Chronique des lettres françaises, París, 1973.

En la elaboración de estas pequeñas fichas bibliográficas se han tenido en cuenta diversas fuentes, pero de manera especial el estudio: Y. CHEVREFILSDESBIOLLES, Les revues d'art à Paris: 1905-1940, París, 1993.

${ }^{16}$ Nord - Sud. Revista literaria. Editada en París, 16 números en 13 fascículos, aparecidos entre 1917 y 1918. Formato: $24 \times 13 \mathrm{~cm}$. Director Pierre Reverdy. Reimpresión: Nord-sud; Editions Jean-Michel Place, París, 1980 
modernistas (sic). Tal carácter subversivo está más acentuado en la revista Littérature (cuyo título significaba, por antífrasis, 'AntiLiteratura'"'17.

[Fig. 4] Sin abandonar nunca por completo ese bagaje, particularmente la herencia literaria de Apollinaire, la fascinación producida en los de París por el Manifeste Dada 1918, publicado por Tristan Tzara en el no 3 de su revista Dada, situará de inmediato al grupo en el ámbito del dadaísmo internacional. Nada más conocer el "prodigioso manifiesto" André Breton inicia correspondencia con su autor: "Ya no sabía de quien esperar el coraje que usted muestra. Es hacia usted donde hoy se dirige toda mi atención"18, le escribe entusiasmado el 22 de enero siguiente. La participación de los responsables de Littérature en la revista de Tzara es inmediata y desde el no 4-5 de mayo de 1919 y sucesivos, se hacen habituales sus colaboraciones en Dada. Recíprocamente, el activista rumano publica ya en el no 2 de Littérature, asumiendo el papel más genuinamente dadaísta durante toda la primera serie de esta revista. Los 20 números de esa primera serie de Littérature, hasta agosto de 1921, discurrieron así paralelamente a los últimos lanzamientos de Dada: no 4-5 -Anthologie Dada (mayo de 1919), no 6 -Bulletin Dada (1920), no 7-Dadaphone (1920) y no 8 -Dada au grand air (1921), generando una acción común entre ambas publicaciones, aunque con intereses literarios y estilos gráficos muy diversos que prefiguran desde el primer momento conflictos y derivas que serán los que diferencien Dadá y Surrealismo. Este encuentro y complementariedad entre Dada y Littérature es lo que aquí interesa destacar del dadaísmo parisino de posguerra pues, como se ha indicado, no solo preconiza el surrealismo histórico, es ya, como defiende Breton, un surrealismo

${ }^{17}$ G. BAZIN, "Notice historique sur Dada et Surréalisme", L'Amour de l'Art, no 3, marzo 1934 (pp. 340342), p. 340.

18 A. BRETON (Ed. Marguerite Bonnet et alt.), Oeuvres complètes Tome I, París, 2008. Cronología, p. xxxviii. genuino que se concreta y desarrolla en sinergia con el Dadá ${ }^{19}$.

[Fig. 5] Pero la efervescencia del ambiente vanguardista de la inmediata posguerra mantuvo y generó otros periódicos dadaístas. El veterano Francis Picabia es sin duda, junto Tzara, el otro gran agitador y revuiste de Dadá. Colaborador fundamental en Dada de Tzara y, posteriormente, en la segunda serie de Littérature, mantiene su revista $391(1917-1924)^{20}$ que, tras su paso desde 1916 por Barcelona, Nueva York y Zurich, recala finalmente en París entre 1919 y 1924, donde ven la luz los números 9 al 19. Al mismo tiempo, Picabia lanza ácidas críticas desde su tribuna en el periódico Comoedia y crea otra revista: Canibale. Sous la direction de Francis Picabia avec la collaboration de tous les dadaïstes $d u$ monde ${ }^{21}$, que lanza dos números en abril y mayo de 1920 en los que, efectivamente, hallamos a Picabia y Tzara, a Ribemont-Dessaignes y Paul Dermée, y al grupo de Littérature. Sin agotar la nómina citaré una última publicación plenamente dadaísta, el pequeño y distendido cuadernillo Proverbe (1920-1921) ${ }^{22}$ creado por Paul Éluard,

\footnotetext{
19 "Es por lo tanto inexacto, afirma Breton, y cronológicamente abusivo presentar al surrealismo como un movimiento salido de Dadá o considerarlo la reorientación de Dadá hacia el plano constructivo. La verdad es que en Littérature al igual que en las revistas Dadá propiamente dichas, textos surrealistas y textos Dadá ofrecieron una continua alternancia." A. BRETON, Entretiens 1913-1952, París, 1973. p. 62.

20 391. Revista dadaísta dirigida por Francis Picabia. 19 números entre 1917 y 1924 aparecidos en: Barcelona (no 1-4, 1916-17), New York (no 5-7, 1917), Zurich (no 8, 1919), París (n⿳0 9-19, 1919-24). Formato variable de cuarto a gran folio. Reimpresión: 391. Revue publiée de 1917 à 1924, Introducción Michel Sanouillet, Le Terrain Vague, Paris, 1960.

${ }^{21}$ Canibale. Subtítulo: Sous la direction de Francis Picabia avec la collaboration de tous les dadaïstes du monde. Dirigida por Francis Picabia, codirección: Georges Ribemont-Dessaignes. Aparecen 2 números en abril y mayo de 1920 respectivamente, publicados en París. Formato: 15,5 x 23 cm. Reimpresión: Dada francese, Gabriele Mazzotta “Archivi del XX secolo", Milano e Roma, 1970.

22 Proverbe. Feuille mensuelle. Pequeño cuadernillo literario editado por Paul Éluard. Aparecen 6 números
} 
donde a lo largo de sus 6 números se reúne, igualmente al completo, el dadaísmo parisino para lanzar concisos poemas y aforismos: “¡Abajo las palabras!”; "El arte no es más que una vianda blanda y fría, los cubistas se alimentan de esta carne."; "Paso a Dadá que mata"; "Después nuestro, la blenorragia" ${ }^{23}$.

[Figs. 4, 6 a] Aun formando parte del conglomerado Dadá hasta aquí descrito, Littérature mantiene peculiaridades notables respecto a las revistas nacidas en el dadaísmo. Para ilustrar tales contrastes, vale la pena caracterizar brevemente la publicación Dadá que desde un punto de vista editorial y gráfico parece más representativa y, además, como acabamos de ver, muy vinculada a Littérature: la revista Dada (1917-1921) ${ }^{24}$, publicada en su mayor parte por Tristan Tzara, primero en Zurich y después en París. En ella se perfeccionan determinados recursos tipográficos presentados en Sic, hasta ponerlos al servicio de una desigualdad sistemática muy bien expresada por Michel Giroud cuando describe la puesta en página concebida por Tzara: “No es sino con el no 3 (primero debido a Tzara) cuando aparece una nueva revista que rompe con la composición tradicional, mezclando textos y xilografías, dibujos y poemas, rompiendo el orden horizontal con inscripciones oblicuas o verticales, jugando con la variedad de caracteres y dando a los títulos valor de insignia: por primera vez desde 1918, se elabora una dinámica visual ininterrumpida y en todos los sentidos que va a constituir la segunda fase de Dadá y que se convertirá consecuentemente

entre febrero de 1920 y julio de 1921 publicados en París. Reimpresión: Proverbe, Centre du xx siècle de l'Université de Nice, 1978.

${ }^{23}$ Proverbe, $\mathrm{n}^{\mathrm{a}}$ 3, abril 1920, diversas páginas.

${ }^{24}$ DADA. Subtítulos diversos: Recueil littéraire et artistique; Anthologie Dada; Bulletin Dada; Dadaphone; Dada au grand air. Aparecen 8 números publicados en Zurich y París entre 1916 y 1922. Formato variable de cuarto a gran folio. Promotores: Marcel Janco, François Arp y Tristan Tzara, director desde el nº3. Varias reimpresiones, entre ellas: Dada Zürich-Paris, 1916-1922, Éditions Jean-Michel Place, Paris, 1981. en la manera sin manera de Dadá" 25 . Efectivamente, la irregularidad en Dada llega al punto de variar formato y tamaño para cada número y componerlo con pliegos de tinturas diversas. Ningún plan gráfico se percibe. La imagen se establece en paralelo a los textos y su abundancia constituirá una característica muy destacable: xilografías de Janco, Arp o Richter, pinturas de Klee, Kandinsky, Augusto Giacometti, G. de Chirico o importantes dibujos de Picabia, junto a constantes alardes tipográficos. Todo ello convierte las páginas de la revista en un acontecimiento tan visual como poético e impredecible.

[Figs. 3 c, 6 b] Littérature. Primera serie.- Littérature (1919-1924) ${ }^{26}$, financiada inicialmente por Philippe Soupault y dirigida, como sabemos, por André Breton, Louis Aragon y el propio Soupault, era, por el contrario, una revista para leer en la que apenas tuvo cabida la imagen ni los juegos tipográficos. Así fue al menos hasta la llegada de Picabia, ya en su segunda serie, y ni entonces se optó por una integración dadaísta de texto e imagen. Desde el punto de vista de los contenidos hay también que hablar, al fin y al cabo, de una revista literaria que solo en parte muestra esa vocación "antiliteraria" y dadaísta, presentándose más bien como una manifestación muy diversificada del ambiente literario moderno, deudor en algún grado de Apollinaire y sus conceptos de "Espíritu nuevo" y de "Surrealismo"27.

25 M. GIROUD, Daderidada, chanson; en: Dada Zurich-Paris, París, 1981. Introducción p. 9.

${ }^{26}$ Littérature. Revista literaria editada en París. Dos series: $1^{\text {a }}$ serie, 21 números, marzo de 1919 - agosto de 1921; 2ª serie, 13 números, marzo de 1922 - junio de 1924. Formato: $1^{\underline{a}} 14 \times 22,2^{\underline{a}} 18 \times 23 \mathrm{~cm}$. Directores: $1^{\underline{a}}$ serie: Louis Aragon, André Breton, Philippe Soupault. $2^{\underline{a}}$ serie: $n^{-} 1$ A. Breton, P. Soupault; $n^{\circ} 4$ A. Breton; $n^{-1} 13$ Max Morise. Reimpresión: Littérature; Ed. Jean-Michel Place, 2 tomos, París, 1978.

${ }^{27}$ Apollinaire propone hacia 1917 los conceptos de Esprit nouveau y Surréalisme; ambos hallarán un brillante futuro en los años 20 del siglo. Es en el prólogo a Les Mamelles de Tirésias (Drame surréaliste) donde acuña su afortunado neologismo: "Para intentar, sino una renovación del teatro, al menos un intento, he pensado que había que volver a la naturaleza misma, pero sin imitar- 
Reparemos, para ilustrar esto, en algunos de los colaboradores presentes e incluso asiduos en la primera serie de Littérature: André Gide, Paul Valery, André Salmon, Max Jacob, Pierre Reverdy, Blaise Cendrars, Maurice Raynal; personalidades que desde cierta tradición simbolista apostaron por una renovación moderna bien representada por Apollinaire y cuyo paradigma artístico fue el cubismo.

Junto a tan prestigiosos literatos de la generación anterior -muchos de los cuales serán después agriamente negados- los jóvenes directores de la revista que aún les mostraban sincero respeto, comienzan a publicar, al tiempo que los propios, textos inéditos de sus referentes: Stéphane Mallarmé, Isidore Ducase, Arthur Rimbaud, Jacques Vaché, Guillaume Apollinaire. La acción de Breton, Aragon y Soupault en Littérature tuvo pronto una asombrosa fuerza magnética para los jóvenes, los futuros compañeros de surrealismo, que se irán integrando en el proyecto. Paul Éluard se aproxima a Breton a comienzos de 1919 y publica desde el no 3; Benjamín Péret y Max Ernst lo hacen hacia finales de 1920 y, ya en la 2ª serie de la revista, se sumarán Roger Vitrac, Jacques Baron o Max Morise. Así pues, la primera serie de Littérature mantendrá un carácter híbrido y muy sincrético dentro de las vanguardias literarias del momento, derivado de la diversidad de procedencias estéticas y generacionales de sus escritores. Tal formulación, en definitiva literaria, permitió una puntual periodicidad mensual y la muy notable tirada de 1500 ejemplares y 200 abonados, al menos durante el primer año; el propio Breton se refirió a Littérature como "una revista de muy buena compañía" 28 .

De forma simultánea a las aportaciones netamente literarias de los colaborado-

\footnotetext{
la como hacen los fotógrafos. Cuando el hombre quiso imitar el caminar, creó la rueda que no se parece a una pierna. Hizo así surrealismo sin saberlo." G. APOLLINAIRE, Les Mamelles de Tirésias, París, 2009, p. 114.

${ }^{28}$ M. BONNET, Littérature et le reste..., p. VII; en:
} Littérature, París, 1978. res asociados a la generación de Apollinaire, los directores de la publicación y otros que van llegando, se entregan a descubrimientos fundamentales como la poesía de Isadore Ducase, Conde de Lautréamont, las cartas de Jacques Vaché, Freud, etc. e inician experiencias protosurrealistas. En los números 8, 9 y 10 (final de 1919) se publican fragmentos de Les Champs Magnétiques, primeras experiencias de escritura automática y relatos asimilables al sueño, obra debida a la colaboración de Soupault y Breton ${ }^{29}$; después, ya en 1922, comenzarán ciertas experiencias fundamentales sobre sueño inducido. También durante aquellos meses finales de 1919 comienza en la revista una práctica fundamental del surrealismo las Enquêtes, lanzando en el no 9 de noviembre la pregunta: Pourquoi écrivez-vous? cuyas respuestas serán publicadas a lo largo de varios números.

[Figs. 2, 6] Acción Dadá.- Literatura, surrealismo (cuyo nombre es aún Dadá) y, ciertamente, Dadá "clásico" con sus manifiestos y actividades públicas. Este tercer aspecto de Littérature, sostenido siempre en cualquier caso por las aportaciones de Tzara, se pone de manifiesto más explícitamente en sus entregas de 1920, coincidiendo con el período de mayor actividad dadaísta en París, sus célebres soirées y otros acontecimientos desarrollados en locales públicos y bien publicitados. El no 13 de mayo de 1920 se presenta con grandes tipos en portada: Ving-trois manifestes du mouvement Dada ${ }^{30}, 23$ manifiestos que habían sido leídos en diversas sesiones públicas durante el mes de febrero precedidos por uno común: "No más pintores, no más literatura, no más escultores, no más religiones, no más republicanos, (...) no más policía, no más patrias, ya no está bien de todas estas imbecilidades, no más nada, no más nada, nada, nada, nada, nada. / De este

29 Publicado como libro en 1920 por NRF/Gallimard, será considerada por Breton como la primera obra cumplidamente surrealista.

${ }^{30}$ Sus autores, tal como aparecen en la portada del fascículo, son los siguientes: Picabia, Aragon, Breton, Tzara, Arp, Éluard, Soupault, Serner, Dermée, Ribemont-Dessaignes, Céline Arnault y W. C. Arensberg. 
modo esperamos que la novedad, que será lo mismo que aquello que ya no queremos, se impondrá menos podrida, menos egoísta, menos mercantil, menos obtusa, menos inmensamente grotesca. / Vivan las concubinas y los concubistas. Todos los miembros del Movimiento DADA son presidentes" ${ }^{\prime 31}$.

La militancia Dadá del grupo de Litterature culmina con este número de su revista. Algo solo comprensible en el contexto de la intensa actividad pública desarrollada coincidiendo con la llegada de Tzara a París en enero de 1920. Poco antes de la salida del fascículo de los 23 manifiestos, el grupo alquila la Salle Gaveau para el Festival Dada que tuvo lugar el 26 de mayo de 1920, auténtica apoteosis del Dadá parisino, Dada à $\mathrm{Pa}$ ris, el artículo de Hugnet que ahora retomamos, ofrece algunas imágenes hoy célebres de la memorable sesión. En una de ellas el público aparece manifiestamente inquieto, se está representando La deuxième aventure de M. Aa l'antipyrine de Tzara -un texto que se publica en el siguiente $\mathrm{n}^{\mathrm{o}} 14$ de Littérature-, al acabar la pieza, según relata Hugnet, ante "una sala a rebosar para ver a todos los dadas hacerse rapar el cabello en escena", tal como prometían los pasquines, los dadaístas estaban cubiertos, como el resto del escenario, de huevos lanzados por los espectadores; otros dicen que también trozos de carne. Estos acontecimientos, que se multiplicaron especialmente a lo largo de 1920 y 1921 con festivales, exposiciones con sonados vernissages, excursiones, etc., con revestir un indudable halo lúdico, fueron parte "seria" del dadaísmo y ocasión de encuentros y desencuentros. Es el caso de otra manifestación pública del grupo, Salon Dada, Exposition Internationale en la Galerie Montaigne el mes de junio de 1920, en la que surgen algunas disensiones. Aunque se contaba ya con obras suyas, Duchamp declina participar con el célebre y misterioso telegrama enviado desde Nueva York: "Peau de balle", y sus obras son sustituidas, en una curiosa operación proto-

\footnotetext{
${ }^{31}$ Colectivo, "Manifeste du mouvement Dada", Littérature, $\mathrm{n}^{\mathrm{o}} 13$, mayo 1920 , p. 1
}

conceptual, por los números que les habría correspondido según el catálogo que se editó. Breton se inhibe igualmente de esta manifestación, según Hugnet, por encontrarla impropia de un grupo antiliterario y antiartístico, pero la historiografía posterior sitúa, por el contrario, a Breton en la facción moderada del grupo frente al dadaísmo más estricto de Tzara o Ribemont-Dessaignes, preludiando próximos desencuentros.

[Fig. 6 c] Del Proceso Barrès al Congreso de París.- Al tiempo que la participación de literatos no dadaístas comienza a ser más escasa, se perciben otros cambios en la revista, muy particularmente la tímida inclusión de páginas tipográficas y de algunas imágenes. Es en el no 19 de mayo de 1921 cuando hallamos finalmente una imagen, e importante. En un encarte fuera de texto y paginación se reproduce a plena página Relief tricoté, dibujo de Max Ernst que también acompañó al catálogo de su exposición en Au Sans Pareil ${ }^{32}$, ajeno a otra estética y temática que no fuera el aún históricamente inexistente surrealismo. Sin embargo, el cambio que determinará el futuro del grupo en esos meses procede de cuestiones más políticas que estéticas y de decisiones en las que la voz de Breton comienza, y ya no dejará de hacerlo, a adquirir un carácter perentorio y determinante. Es precisamente el mismo mes de mayo en que se celebra la exposición de Ernst cuando Breton y Aragon, inaugurando una duradera bicefalia al frente del surrealismo así como un ritual inquisitorio persistente, incoan "proceso" ficticio aunque formalmente organizado, contra el prohombre Maurice Barrès ${ }^{33}$. Breton preside

\footnotetext{
${ }^{32}$ Se trata de la Exposition Dada Max Ernst celebrada en mayo de 1921 en la librería Au Sans Pareil, sede editorial de Littérature y otras publicaciones vanguardistas. El vernissage fue un sonado acontecimiento dadaísta (en la Fig. 2 aparece una célebre imagen del mismo).

${ }^{33}$ Escritor y político, Barrés era una personalidad ampliamente respetada. Algunos dadaístas como Aragón y el mismo Breton admiraban sus escritos de juventud y de hecho, solo un mes antes del célebre proceso ficticio le habían otorgado muy altas valoraciones en "Liquidation", una extensa tabla dedicada a calificar a
} 
el tribunal dadaísta -llamativas togas y birretes incluidos- que acusa: "Acusación y enjuiciamiento de Maurice Barrès por crimen contra la seguridad del espíritu"34. Los dadaístas de primera generación se desentienden y critican el proceso. Picabia anuncia su ruptura desde Comoedia: "Ahora Dadá tiene un tribunal, abogados; iprobablemente tenga muy pronto gendarmes y un encargado de la guillotina!" 35 . Tzara, manifiesta como "testigo" sus diferencias con el presidente y niega, sorprendido por la seriedad con que es conducido el proceso, toda justicia, incluida la dadaísta. El no 20 de Littérature, del mes de agosto, se dedicó por completo a los debates del Procès Barrès y fue de hecho el último de la serie publicado. Un $n^{0} 21$ que contenía el resto de las actas del proceso se quedó sin publicar, en las pruebas de impresión. La primera crisis importante del movimiento se había consumado y aunque la ruptura del grupo no fuera aún definitiva, con el caso Barrès se vislumbra ya un modo de proceder y unos intereses respecto al entorno social que no son los de Dadá.

[Fig. 7 a, b] Littérature queda en dique seco durante seis meses de $\operatorname{conflictos}^{36}$ y su

escritores y artistas -entre -25 y +25 - aparecida en el $\mathrm{n}^{\mathrm{o}} 18$ de Littérature. (Liquidation es un documento muy significativo para constatar la diversidad de intereses del grupo, en donde se disciernen ya significativas diferencias entre las valoraciones de los dadaístas, especialmente Tzara, y las de los futuros surrealistas.) Como político Barrès fue un nacionalista radical que ante el caso Dreyfus publicó varios escritos antisemitas. La acusación incidía en la traición a sus ideales de juventud en aras del conformismo.

${ }^{34}$ Colectivo, "Le Procès Barrès", Littérature, $\mathrm{n}^{\mathbf{0}}$ 20, agosto 1921, p. 1.

${ }^{35}$ P. DAIX, La Vie quotidienne des surréalistes (19171932), París, 1993. p. 126.

${ }^{36}$ Breton da noticia de ello en caliente: “Una corriente novelesca, nacida de la agitación poética de estos últimos años, ha levantado últimamente unos contra otros a algunos individuos que hasta entonces habían expresado su común deseo aquí mismo y también fuera. En lo más intenso de la crisis (agosto 1921 - marzo 1922) y en ciernes de su resolución (julio - agosto 1922) Littérature deja de aparecer." A. BRETON, "Clairement", Littératire $\mathrm{n}^{\mathrm{o}}$ 4, $2^{\mathrm{a}}$ serie, septiembre 1922, p. 1. segunda serie se inicia en marzo de 1922. Sin embargo, el relanzamiento de la revista va asociado a otra ocasión de conflicto. En enero de 1922 Breton anuncia la convocatoria para el mes de marzo de un Congrès international pour la détermination des directives et la défense de l'esprit moderne, al que serán llamados representantes de todas las sensibilidades de la modernidad, más que por sus concretas visiones de lo moderno, por su firmeza en atajar todo avance de la tradición, y ello en pleno Retour a l'ordre. El comité organizador del que será denominado Congrès de Paris reunió a Roger Vitrac en representación de Aventure ${ }^{37}$, Ozenfant por L'Esprit Nouveau, André Breton por Littérature y una representación de la Nouvelle Revue Française NRF, además los artistas Fernand Léger y Robert Delaunay, y el músico Georges Auric. Su objetivo: articular "las directivas y la defensa del espíritu moderno" y "proceder a la confrontación de los valores nuevos, establecer la relación exacta de fuerzas presentes y precisar tanto como sea posible su resultante" ${ }^{\prime 38}$. Con esta iniciativa, como con el Procès Barrès, Breton quiso resituar la acción Dadá en un "devenir positivo", tal como lo expresa Marguerite Bonnet ${ }^{39}$, inaugurando así la trágica, por constante y nunca resuelta, disyuntiva surrealista entre acción, efectiva y socialmente revolucionaria, y poesía en radical libertad.

Tal confraternización con el modernisme de L'Esprit Nouveau (1920-1925) ${ }^{40}$, antíte-

\footnotetext{
${ }^{37}$ Aventure. Promotores: René Crevel, Roger Vitrac, Jacques Baron, Max Morise y otros. Aparecen 3 números entre 1921 y 1922. formato $22 \mathrm{~cm}$ altura. Reimpresión: Aventure, Ed. Jean-Michel Place, París, 1975. 75 .

38 A. BRETON, Entretiens 1913-1952, París, 1973, p.

${ }^{39}$ M. BONNET, Op. cit., p. xvi.

40 L'Esprit Nouveau. Subtítulo: Revue Internationale Illustrée de l'Activité Contemporaine paraissant le 1er de chaque mois. Arts, Lettres, Sciences. Editada en París, 28 números entre 1920 y 1925. Formato: 25 x 16,3 cm. Dirigida por Paul Dermée, después por Amédée Ozenfant y Le Corbusier. Reimpresión: L'Esprit Nouveau (8 volúmenes), Da Capo Press, New York 1968 y 1969. Le Corbusier reunió muchos de sus propios textos apare-
} 
sis de los ideales dadaístas, colmó el vaso y Tzara, apoyado por una amplísima mayoría del grupo de Littérature, saca en abril de 1922 el primer y único número de Coeur à barbe, Journal Transparent ${ }^{41}$, como instrumento para desbaratar el Congrès denunciando cualquier aproximación al "dogmatismo pretencioso y al culpable positivismo social" ${ }^{\prime 2}$ de la revista del Purismo. Éluard, Soupault, Ribemont-Dessaignes, Péret o Théodore Fraenkel además de Satie, Duchamp o Huidobro, participan en el cuadernillo. Solo Aragon se mantiene firme junto a Breton y, en la distancia, también Picabia que hace pública su simpatía por la iniciativa, solventando así el anterior desencuentro causado por el caso Barrès. La magnitud de la disensión tiene efecto y el Congrès no pasa de los meros preparativos, desconvocándose. Coeur à barbe se hace eco de ello en una Dernière heure: "Los miembros del Congreso del Modernismo, a consecuencia de las amenazas de algunos pérfidos impostores, han decidido hace algunos días abandonar esa excelente idea de circular como perros con correa entre los principios de los célebres teóricos. El Congreso muere de nacionalismo al chocolate, de vanidad en vainilla y de la estupidez casi suiza de algunos de nuestros más precisos conciudadanos" ${ }^{\prime 4}$. Los textos de Coeur à barbe mantienen un tono irónico respecto al Congrès con constantes alusiones, como acabamos de leer, a la potente teoría desplegada por Le Corbusier/Jeanneret y Ozenfant desde su extraordinaria L'Esprit Nouveau, pero no son directamente lesivos para con Breton. Habrán de pasar muchos años para que Tzara se rencuentre en proyectos surrea-

cidos en la revista en: LE CORBUSIER, L'Art decoratif d'aujourd'hui, G. Crès et Cie, París, 1925.

${ }^{41}$ Le Coeur à barbe. Journal Transparent. Promotores: Tristan Tzara, director y Georges Ribemont-Dessaignes. Un solo número en abril de 1922. Formato 14 x 22,5 cm. Reimpresión: Le Coeur à barbe. Journal Transparent, Ed. Jean-Michel Place, París, 1981.

${ }^{42} \mathrm{Y}$. CHEVREFILS-DESBIOLLES, Les revues d'art à Paris: 1905-1940, París, 1993, p. 82.

${ }^{43}$ Sin firma, Le Coeur à barbe, no 1 , abril 1922, p. contraportada. listas con él, pero pocas semanas para que la mayor parte de los ofendidos por el nuevo pragmatismo social del poeta vuelvan a Littérature.

[Figs. 7 c, 8, 9] Littérature. Segunda serie.- Tras la interrupción y los acontecimientos relatados, Littérature $2^{\mathrm{a}}$ serie saca su no 1 en marzo de 1922 editando 13 más hasta junio de 1924. Los cambios son importantes. Es otra revista tanto en su formato como en la compacta nómina de sus colaboradores que, desprovista ahora de herederos del simbolismo y compañeros de Apollinaire está netamente formada por el núcleo de lo que pronto será el grupo surrealista, incluyendo a Péret, Vitrac o Baron como habituales. La pérdida para Littérature de Tzara desde el caso Barrès, es compensada por la activa incorporación de Picabia que adquirirá un papel decisivo en esta segunda serie con sus textos y con sus diseños de portada. Estos sustituirán al mantenido en los tres primeros números la serie, el célebre Chapeau haut-deforme del que surge el título, debido al recién llegado a París, Man Ray.

[Fig. 8 b, c] Pero incluso con Picabia, el dadaísmo no se recuperó tras el asunto del Congrès, las figuraciones de sus propias portadas hablan de otro momento: de nuevo puede haber cuerpo y deseo más allá de las metáforas maquinistas de Dadá. Las tres primeras entregas de la $2^{\underline{a}}$ serie son, como reconoce Breton, de transición: "Entre tanto Philippe Soupault y yo probamos, sin demasiada fortuna, generar diversión: números del sombreo de copa. Pero nos dimos cuenta bastante pronto de que nos debíamos a un compromiso" $^{\prime 4}$. En el no 4 de septiembre de 1922, después de una interrupción de algunos meses, André Breton toma la dirección en solitario de Littérature. Tras la primera portada debida a Picabia: un gran Sagrado corazón rojo, presenta Clairement, una declaración solemne -otra práctica que se inaugura para las revistas del surrealismo- en la que se hace balance de la situación del grupo,

\footnotetext{
${ }^{44}$ A. BRETON, “Clairement”, Op. cit., p. 1.
} 
cuya grave crisis estaría ya resuelta ${ }^{45}$, también algunos ajustes de cuentas, en particular con Tzara hacia quien manifiesta su decepción y, finalmente, se dirige al futuro del movimiento: “Gracias a Dios, nuestra época está menos envilecida de lo que se dice: nos quedan Picabia, Duchamp, Picasso. Os saludo y doy la mano, Louis Aragon, Philippe Soupault, mis queridos amigos de siempre. (...) Pero ya nos esperan Jacques Baron, Robert Desnos, Max Morise, Pierre Massot. Nunca se dirá que el dadaísmo haya servido para otra cosa que para mantenernos en este estado de disponibilidad perfecta en que nos hallamos y del que ahora nos vamos a alejar lucidamente hacia lo que nos reclama" ${ }^{46}$.

Así da el propio Breton por cerrado el ciclo dadaísta del grupo aglutinado alrededor de Littérature. Aún no se sabe lo que les reclama o, por lo menos, aún no ha recibido abiertamente el nombre de surréalisme en su acepción bretoniana, pero lo cierto es que los contenidos de Littérature $2^{\underline{a}}$ serie prefiguran ya claramente el imaginario del Manifeste $d u$ surréalisme. Textos sobre Lautreamont, Raymond Roussel o Freud que continúan un camino emprendido en la $1^{\underline{a}}$ serie, relatos de sueños presentes en varios números, el acendramiento en la escritura automática, etc. Pero entre estas manifestaciones de una sensibilidad ya surrealista hay que reparar en las experiencias hipnóticas antes citadas, COmenzadas en septiembre de 1922 y protagonizadas sobre todo por nuevas adscripciones al grupo, René Crevel y Robert Desnos. Los sommeils médiumniques de este último, apodado Le prophète, resultaban especialmente comunicativos, desarrollando además una rara habilidad para representarlos con dibujos, cuando, según se afirmaba, él carecía de tal habilidad en estado consciente. La curiosidad del grupo hacia estas experiencias, por así decir, "reales" de automatismo fue grande, sin embargo, serán detenidas por Breton a inicios del año siguiente ante el peligroso cariz de dependencia y agresividad

\footnotetext{
${ }^{45}$ Ver nota 36.

${ }^{46}$ A. BRETON, "Clairement", Op. cit., p. 2.
}

que comenzaron a tomar. Pero ahí estaba ya en primer plano el sueño y la manifestación del inconsciente, y Littérature se ocupará de ello extensamente. En Entrée des médiums, el artículo que abre el no 6 de noviembre de 1922 ocupando 2/3 de su paginación, Breton describe y transcribe sesiones hipnóticas con Crevel, Desnos y Péret. El relato está precedido por un preámbulo que nos sitúa ya en una acepción "surrealista" del término acuñado por Apollinaire: "Se sabe, hasta cierto punto, lo que mis amigos y yo entendemos por surrealismo. Nosotros empleamos esta palabra, que no es de nuestra invención y que muy bien podríamos haber abandonado al más vago vocabulario crítico, en un sentido preciso. Mediante ella hemos convenido en designar un cierto automatismo psíquico que se corresponde bastante bien con el estado del sueño, estado que es actualmente muy difícil de delimitar"47. Pero, más allá de las designaciones, estos textos hablan ya de una investigación sistemática del inconsciente, y con ello, Dadá comienza a alejarse.

[Figs. 8 a, 9] El siguiente fascículo de Littérature, $\mathrm{n}^{\mathrm{o}} 7$ de diciembre, se ilustra con uno de esos dibujos sobrevenidos de Robert Desnos. Se trata de otro aspecto fundamental en la formación del surrealismo, el reconocimiento otorgado a la imagen cuyo correlato es un creciente interés, por otra parte siempre presente en Breton, hacia las artes visuales. Aunque muy lejos de la abundancia visual de la revista de Tzara, Littérature $2^{\underline{a}}$ serie se abre a la imagen y ya en su primera entrega ofrece en hors-texte (páginas de imagen ajenas a la paginación y articulado), Le cerveau de l'enfant de G. de Chirico, como es sabido, gran icono magnético del imaginario surrealista $^{48}$. Hay, no obstante, que esperar al n 5 para hallar más imágenes pero desde este fascículo la inclusión de uno o dos fuera

${ }^{47}$ A. BRETON, "Entrée des Mediums", Littérature, no 6, 2aㅗ serie, noviembre 1922 (pp. 1-16), pp. 1-2.

${ }^{48}$ Breton y pocos años después Tanguy, se vieron igualmente impelidos a bajar de la plataforma del autobús en que viajaban al vislumbrar este cuadro en el escaparate del marchante Paul Guillaume. 
de texto será la norma. En ese no 5 hallamos dos de estas páginas, y la afirmación de un nuevo artista: Man Ray, que llega al grupo de la mano de Marcel Duchamp. Man Ray presenta su célebre paisaje de polvo Élevage de poussière titulado aquí: Vu prise en aéroplane o Voici le domaine de Rrose Sélavy en la apropiación duchampiana, en la otra página, aparece la entrada-escaparate de un comercio que muy bien podría haberse reservado para $L a$ Revolution surréaliste. Poco después, en el no 9, todavía otra primicia de Man Ray, el rayograma Monsieur..., Inventeur, Constructeur, 6 Seconds, una de las primeras revelaciones de esta técnica fotográfica que RibemontDessaignes llamaría Objets du rêve. También hallamos a Picasso y Arp. Destacar, para terminar este apartado visual de Littérature, el papel de Max Ernst con sus numerosos dibujos, así como el fundamental de Picabia entre cuyas imborrables portadas se halla uno de esos retratos de grupo que identifican constantemente al surrealismo como acción colectiva. En este caso se reúnen como flores en un ramillete; André Breton sería la más destacada.

Tras ese no 9 de febrero-marzo de 1923 que integraba el rayograma de Man Ray, la revista deja de editarse. Durante ese verano se escenifica la ruptura con el dadaísmo de Tzara, en realidad hacía tiempo efectiva, pero ahora, además, con la idea misma de dadaísmo. El grupo más próximo a Breton boicotea violentamente la Soirée Dada del Teatro Michel, Soirée coeur à barbe, organizada por Tzara. En una batalla campal Breton rompe con su bastón el brazo a Pierre de Massot, uno de los dadaístas, Éluard cae sobre el decorado; Tzara llama a la policía y pide daños y perjuicios. "Olvidemos tales incidentes, pidió Breton, ya que ha empezado la era del surrealismo propiamente dicho" ${ }^{49}$. Tras esos acontecimientos el distanciamiento de Dadá parece urgir a los de Littérature que niegan su anterior compromiso: "Mis amigos, afirma de nuevo Breton, Phillippe Soupault y Paul Éluard no me llevarán la contraria: nunca

\footnotetext{
${ }^{49}$ A. BRETON, Oeuvres complètes, Op. cit., p. xlvi.
}

consideramos a Dadá sino como la imagen grosera de un estado de espíritu que, además, Dadá no ayudó a crear en absoluto" ${ }^{\prime 50}$. Para cuando se recupera la edición de Littérature con su $\mathrm{n}^{\mathrm{o}}$ 10-11 del mes de octubre -un fascículo especial dedicado a la poesía, ampliamente ilustrado por Max Ernst- el grupo, aunque ya prácticamente coincidente con el futuro núcleo del grupo surrealista, manifiesta síntomas de desgaste y disgregación. El no 13 y último de la serie es calificado por sus propios responsables de "desmoralizante" en el sentido de no hallar ya en lo literario suficiente amplitud de acción. Roger Vitrac escribe Ma collaboration à Littérature ${ }^{51}$ y bajo tal título se extiende premonitoria el resto de la página en blanco. La desmoralización fue real, Breton había anunciado en abril de 1923 que no escribiría más y Éluard desaparece a comienzos de 1924 en un misterioso viaje alrededor del mundo. Una nota del grupo consignada en la prensa anuncia ese último número de Littérature aparecido en junio de 1924: "(el grupo) publica su último número, no falto de posibilidades materiales, sino de razones suficientes de existencia. Los colaboradores habituales de esta revista tienen la intención de consagrarse al surrealismo en la poesía y sobre todo en la vida" ${ }^{\prime 2}$.

\section{EL “PARTIDO DEL SUEÑO”}

[Fig. 10] Surrealismo, orígenes y usos.- Al tiempo que el número desmoralizante de Littérature veía la luz, Breton-como siempre supo hacer con las numerosas crisis del grupo- convertía en acción positiva tal estado de ánimo, dando forma específica a un proyecto renovado que quedará expresado a los pocos meses en su Manifieste du surréalisme ${ }^{53}$. La superación de lo literario, anti-

\footnotetext{
${ }^{50}$ G. PICON, Diario del surrealismo, Ginebra, 1981, p. 40 .

${ }^{51}$ R. VITRAC, "Ma collaboration à Littérature", Littérature, $\mathrm{n}^{\mathrm{o}} 13$, 2aㅡ serie, junio 1924, p. 11.

${ }^{52}$ Y. CHEVREFILS-DESBIOLLES, Op. cit., p. 83.

53 A. BRETON, Manifeste du surréalisme, Éditions du Sagittaire chez Simon Kra. París, octubre 1924, 190 pág.
} 
littérature, era ya expresa en las experiencias de escritura automática desarrolladas, como vimos, en Littérature por Soupault y Breton. En el Manifieste, tras algunas disquisiciones sobre el sueño como manifestación privilegiada de lo "maravilloso", se aludirá detalladamente a aquellas experiencias, suerte de resolución del conflicto entre sueño y realidad, afirmando que ya entonces recibieron el nombre de surrealismo: "Soupault y yo dimos el nombre de SURREALISMO al nuevo modo de expresión que teníamos a nuestro alcance y que deseábamos comunicar lo antes posible, para su propio beneficio, a todos nuestros amigos" ${ }^{54}$. La herencia de Littérature se adscribe de este modo al movimiento surrealista.

Pero existían, además, otras razones para esa precisión acerca de la utilización y origen de la denominación surrealismo, cuyo uso no fue tan generalizado ni significativo como parece desprenderse del relato de Breton, hasta el propio año 1924. Durante todo este año los componentes del grupo que aún se organiza alrededor de Littérature, mantienen una extraordinaria actividad editorial en medios literarios abiertos. Publican ampliamente en la Nouvelle Revue Française (N.R.F.), Paris-Journal, Revue Européenne, etc. $\mathrm{y}$, efectivamente, comienzan a ser conocidos como surréalistes. Tanto su ubicuidad como la propia aducción del término "surrealismo" generó fuertes suspicacias y oposición, dando lugar, incluso antes de la publicación del Manifeste, a una suerte de campaña espontánea orquestada desde distintos frentes contra ellos. Recientes compañeros como el propio Picabia y Ribemont-Dessaignes procuran desde una nueva serie de 391, que reaparece con sus últimas cuatro entregas en 1924, desestabilizar los nuevos derroteros -“examinarlo todo a la luz de la muerte y del sueño", en palabras de M.-C. Bancquart ${ }^{55}$ tomados por sus colegas en Dadá. El intento culmina en la cuarta entrega, el no 19 de 391,

${ }^{54}$ A. BRETON, Manifiestos del surrealismo (Trad. Andrés Bosch), Madrid, 2002, p. 33.

${ }^{55}$ M.-C. BANCQUART, Op. cit., p. v. donde se lanza un nuevo ismo que oponer al apropiado por Breton, el Instantanéisme $e^{56}$. Otros son más explícitos en su ataque, así Paul Dermée que desde su efímera revista $L e$ Mouvemet accélére, escribe Pour en finir avec le surréalisme $^{57}$. Por su parte, algunos albaceas de la herencia de Apollinaire protestan contra la usurpación de un concepto básico de su literatura, creando, semanas antes de la publicación del Manifeste, la revista Surréalisme $^{58}$ en la que su director Ivan Goll o, por ejemplo, Albert-Birot y Pierre Reverdy, apelan a su tradición literaria como único significado y uso legítimo de "surrealismo". Goll defiende en su propio Manifeste $d u s u$ rréalisme, contenido en la citada revista, un surrealismo que "significa lo saludable", ajeno a "tendencias de descomposición y mórbidas" $" 59$.

\section{MANIFIESTO DEL SURREALISMO}

Esta pequeña Querelle se decanta sin más en favor del renovadamente intenso grupo centrado en Breton; Picabia, como en la anterior ocasión, recuperará enseguida el trato con los surrealistas. En su Manifeste, Breton admite un homenaje explicito a Apollinaire al apropiar su concepto, pero defiende que la significación por ellos atribuida al mismo era ya muy diversa y, además, la que desde la época de su colaboración con

${ }^{56}$ En la portada del cuadernillo no 19 de 391 puede leerse sobre una efigie de Marcel Duchamp: "Instantaneísmo: No quiere ayer; No quiere mañana; Hecho de saltos; Hecho de alas de pingüinos; No quiere grandes hombres; Solo cree en el presente; Quiere la libertad para todos; Solo cree en la vida; Solo cree en el movimiento perpetuo." Sin firma, 391, no 19, noviembre 1924.

57 Le Mouvement accéléré. Organe accélérateur de la Révolution artistique et littéraire. Un número, noviembre 1924. Formato: $30 \times 42 \mathrm{~cm}$.

58 Surréalisme. Director Ivan Goll. Un solo número en octubre de 1924. Formato: 17 x 24,5 cm. Reimpresión: Surréalime, Édition établie et présentée par Jean Bertho, Ed. Jean-Michel Place, París, 2004. El sentido dado a la palabra por Apollinaire fue comentado en la nota 30.

${ }^{59}$ M.-C. BANCQUART, Op. cit., p. v. 
Soupault se impuso ${ }^{60}$. El Manifieste du surréalisme reúne también la herencia surrealista de la segunda etapa de Littérature cuando, al enumerar detalladamente a sus amigos de ese momento -habituales de su apartamento de la calle Fontaine, "habitantes del castillo de lo maravilloso" - reorganiza ese bagaje dando carta de naturaleza a un compromiso grupal explícito mediante la célebre fórmula: "Han hecho profesión de fe de SURREALISMO ABSOLUTO, los siguientes señores: Aragon, Baron, Boiffard, Breton, Carrive, Crevel, Delteil, Éluard, Gérard, Limbour, Malkine, Morise, Naville, Noll, Péret, Picon, Soupault, Vitrac." La lista, ensanchada respecto a los sumarios de Littérature y sin conjunción que la cierre, es necesariamente más amplia. El surrealismo, se afirma en el Manifeste, es una manifestación humana que aflora en la libertad conquistada por literatos y artistas, por filósofos o científicos: Sade, Hugo, Poe, Baudelaire, Jarry, etc. fueron surrealistas en algún aspecto -Rimbaud en todos-; Uccello, Moreau, Seurat, Matisse, Derain, Picasso -"el más puro con mucho"Braque, Duchamp, Picabia, de Chirico, Klee, Man Ray, Ernst, Masson, "escucharon la voz surrealista" 61 .

Sin ser el primer texto declarado como surrealista, el Manifeste, que en realidad surgió como prólogo a Pez soluble, convierte intuiciones y prácticas ya discutidas y probadas en el grupo, en corpus ideológico de un movimiento total cuya vocación revolucionaria tenía como objetivo, más allá de la literatura o el arte, la vida. Efectuando previamente la crítica al realismo en literatura, Breton postula como única vía de superación, la imaginación y su correlato en el mundo, lo maravilloso, esto sí realidad plena a la medida de los requerimientos de la inteligencia y el deseo humanos. Ve en el sueño una manifestación de la potencia de lo maravilloso y en la ciencia psicoanalítica pruebas constatables de su realidad ajena a

${ }^{60}$ A. BRETON, Manifiestos del surrealismo, Op. cit., pp. 32-33.

${ }^{61}$ Ibid., p. 35. fantasías; en la escritura automática pruebas de su posibilidad literaria. Finalmente, antes de desgranar cierta casuística surrealista, con sus ilustraciones literarias, se propone la muy conocida pero imprescindible definición: "SURREALISMO: Sustantivo, masculino. Automatismo psíquico puro por cuyo medio se intenta expresar, verbalmente, por escrito o de cualquier otro modo, el funcionamiento real del pensamiento. Es un dictado del pensamiento, sin la intervención reguladora de la razón, ajeno a toda preocupación estética o moral" 62 .

[Figs. $10 \mathrm{~d}, 11]$ Los órganos de difusión de un grupo ampliado.- Desde el fin del verano de 1924, cuando el Manifeste du surréalisme se hace público, el grupo ahora formalmente surrealista comienza una actividad muy intensa cuya manifestación más significativa es la creación el 11 de octubre del Bureau de recherches surréalistes, una oficina abierta al público en general que se anunció en ese momento con un comunicado enviado a la prensa, después reproducido en La Révolution surréaliste: "La Oficina de investigaciones surrealistas se aplica a recopilar por cualquier medio apropiado, las comunicaciones relativas a las diversas formas que es capaz de adquirir la actividad inconsciente del espíritu. Ningún ámbito queda especificado a priori para esta empresa y el surrealismo se propone reunir el mayor número posible de datos experimentales, con un fin que aún no puede hacerse presente" 63 .

La tensión entre el sueño, como principal objeto de investigación de este primer surrealismo de manifiesto, y el temor a caer en la fantasía y el juego intelectual manifestado en el tono investigador y objetivo del Bureau, alude ya a una comprensión madura y vanguardista de lo surrealista como realismo ampliado cuyo lugar y objeto es el mundo y cuya responsabilidad tiene dimensión social. Estas preocupaciones están muy pre-

\footnotetext{
${ }^{62}$ Ibid., p. 34.

${ }^{63}$ Colectivo, "Bureau de Recherches", La Révolution surréaliste, nํㅡㄹ enero 1925, p. 31.
} 
sentes en el principal proyecto en que se ocupa el grupo durante aquellos últimos meses de 1924, la creación de una revista orgánica acorde con los ahora expresos presupuestos surrealistas. La Révolution surréaliste, LRS, $(1924$ - 1929)64 lanza el primero de sus 12 números el mes de diciembre eligiendo para su portada precisamente una frase de Une vage de rêves de Aragon: "Se trata de alcanzar una nueva declaración de los derechos del hombre"; sobre ella, reforzando la idea fundamental de acción colectiva, un montaje de fotografías del grupo. Las investigaciones del en ocasiones denominado parti $d u$ rêve, habían de incidir revolucionariamente en el mundo y tal frase dispuesta en una portada por lo demás muy sobria, como la de cualquier revista científica, debía contribuir a conjurar en la nueva publicación una imagen nihilista ya ajena a los objetivos del grupo.

Y, efectivamente, fue esta cuestión de imagen y formato lo que ocupó en primera instancia las deliberaciones acerca del modelo de revista conveniente. Robert Desnos y Pierre Naville, especialmente, rechazaron pervivencias dadaístas como la disparidad de color en las páginas o las fantasías tipográficas. Se elige un formato neutro inspirado en La Nature de Éditions Masson ${ }^{65}$, una publicación propia de las ciencias positivas, que avalaba los objetivos perfectamente veraces y constatables de sus investigaciones, pues había que remarcar que el surrealismo existe. Por otra parte, el tamaño en folio decidido marcaba distancias con la publicación literaria, cuyas revistas, como la propia Littérature, se presentaban en cuarto. Persistieron, no obstante, prácticas editoriales de

${ }^{64}$ La Revolution surréaliste. (Órgano del grupo surrealista) Aparecen 12 números en 11 fascículos editados en París entre 1924 y 1929. Directores: Pierre Naville y Benjamin Péret; no 4 André Breton. Gerente: Louis Aragon. Formato: 20,5 x 29,5 cm. Reimpresión: La Révolution surréaliste $n^{\circ} 1$ à 12, 1924-1929, Ed. Jean-Michel Place, París 1975-1991, Presentaciones: Marie-Claire Bancquart; Georges Sebbag (1991)

65 Se trata de una casa editorial dedicada a textos científicos, biológicos y médicos fundada en 1804 y que mantiene hoy su actividad.
Dadá, aunque limitadas a las páginas que portaban las abundantes proclamas y manifiestos, tracts, pero lo que sobre todo persistió del espíritu dadaísta fue la intensa ironía, lo equívoco y el gusto por el escándalo presentes en infinidad de textos, noticias e imágenes, como la inefable fotografía "Nuestro colaborador Benjamín Péret injuriando a un cura"66. Hay con esto que dar la razón al propio Breton cuando afirmaba retrospectivamente que el espíritu dadaísta así como el surrealista convivieron tanto en el período propio de Dadá como en el posterior del surrealismo y en absoluto se habría tratado de un mero suceder el uno al otro ${ }^{67}$. Aun con tales pervivencias dadaístas -o precisamente por ellas- la analogía científica de La Révolution surréaliste, caracteriza otro rasgo del surrealismo que añade aun más espesor a la ecuación libertad poética/acción social: el surrealismo es también rigor científico y hechos constatables.

\section{POESÍA Y REVUELTA}

[Figs. 11, 12] La Révolution surréaliste.- Breton mantuvo una posición discreta en los inicios del nuevo proyecto editorial. Pierre Naville, procedente de L'Oeuf dur (1921 - 1924) ${ }^{68}$ y con un importante papel en la creación del Bureau de recherches muy acorde con su perfil marcadamente político, y Benjamin Péret asumieron la dirección de La Révolution surréaliste durante sus tres primeros números. De esta dirección surge, como indicaba, una revista sobria que pone el acento en los contenidos y en la investigación surrealista tal como muy seriamente se indica desde el primer texto del no 1 , una breve declaración de intenciones: "El surrealismo no

\footnotetext{
${ }^{66}$ Imagen por sí misma intrascendente pero aparecida con tal pie de texto en La Révolution surréaliste, $\mathrm{n}^{\circ} 8$, diciembre 1926, p. 13.

67 Ver nota 19.

${ }^{68}$ L'Oeuf dur. Revista literaria dirigida por Gérard Rosenthal en la que colaboraron surrealistas como Aragon, Soupault o Pierre Naville. Jean Cocteau dibuja varias de sus portadas. Aparecen 16 números editados en París entre 1921 y 1924.
} 
se presenta como la exposición de una doctrina. (...) Los resultados obtenidos por la escritura automática, el relato del sueño, por ejemplo, están presentes, pero ninguno de los resultados de encuestas, experiencias o trabajos han sido aún consignados: hay que esperarlo todo del porvenir" ${ }^{\prime \prime 9}$. Salvo su paso desde el $\mathrm{n}^{\mathrm{o}} 6$ de una cubierta de rojo intenso a otra simplemente blanca, el aspecto gráfico de la revista se mantendrá sin grandes variaciones durante sus cinco años de existencia a pesar de los cambios de casa editorial. Aunque estos rasgos conceptuales y gráficos esenciales permanecerán toda la existencia de la revista, la dirección bicéfala de Naville y Péret caracteriza una etapa precisa. Sus tres números entre diciembre de 1924 y abril de 1925, están marcados por el acelerado proceso de expansión del grupo a lo largo del año 1924 que recibe adscripciones individuales: Antonin Artaud, Michel Leiris o el propio Naville, y grupales, como algunos cenáculos vanguardistas de la ciudad: el de la calle Bomet, en torno al taller de Masson: Dubuffet, Limbour, Miró, Malkine, también Leiris, lo frecuentan, o bien, algo después, el de la calle del Chateau, donde se reúnen Duhamel, Prevert, Tanguy. La riqueza de registros así como la radicalidad con que se proponen, va más lejos y se hace más efectiva que en su precedente Littérature.

Así, por ejemplo, el no 2 de LRS: En Le suicide est-il une solution? se consignan las respuestas dadas a una Enquête lanzada en el $\mathrm{n}^{\mathrm{o}} 1$ y presentada como sigue: "Se vive, se muere. ¿Qué parte tiene la voluntad en todo esto? Pareciera que se mata como se sueña. No es una cuestión moral lo que proponemos: ¿Es el suicidio una solución?"; poco después y en pliego o doble página aparecen deslumbrantes y sin explicación alguna varios dibujos de la serie Constellations de Picasso; más allá, un tract o panfleto colectivo de tono anarquista, Ouvrez les prisons $l i$ cenciez les armes: “Nada, ni el reconocimiento cumplido de una falta, ni la contribución a la

${ }^{69}$ Editorial, La Révolution surréaliste, $\mathrm{n}$ 10 1, diciembre 1924, contraportada primera. defensa nacional, podría forzar al hombre a renunciar a su libertad. La idea de prisión, la idea de caserna, es hoy moneda corriente: estas monstruosidades ya no os sorprenden"70; finalmente, ya en la sección Chroniques, Desnos insiste en la muerte, uno de los grandes temas en el inicio de LRS, Crevel y Leiris en el sueño, Aragon en la política. Y siempre, en esta nueva revista de los surrealistas, las imágenes, de toda procedencia, artísticas o no, como la que preside el inicio de Chroniques en la que se vislumbra la lucha de un hombre con un reptil, sumergidos en un líquido oscuro; de nuevo la muerte. Según M.-C. Bancquart, una disparidad, antilógica, veloz y autodestructiva: "Se pone en cuestión la personalidad misma, se sueña con un flujo anónimo del espíritu. Se desconfía, en consecuencia, de la escritura, que es una mordaza"71.

[Fig. 13] El momento de Antonin Artaud.- La última sección de la revista es $B u$ reau de Recherches. Poco más arriba, hubo ocasión de conocer cuales eran los objetivos del Bureau, que se anunciaba destacadamente ya en la contraportada primera del $n^{0} 1$, junto a un pez surrealista y bajo la declaración antes citada. Ahora, en esa misma sección del $\mathrm{n}^{\mathrm{o}} 2$ de la publicación, se hace un balance aceptable del eco hallado por la iniciativa y de los resultados obtenidos en el que, sin embargo, las dudas acerca de la viabilidad del Bureau se dejan traslucir. En realidad la participación ajena al grupo fue testimonial y se toma la decisión de reconvertir la oficina en plataforma de investigaciones y debate interno. Así, la nota que se acaba de citar se complementa contradictoriamente con un Avis que da noticia de su cierre al público y su puesta bajo la dirección de Antonin Artaud. Este, dirigirá el Bureau y también, de hecho, la tercera entrega de la revista que se pone bajo su responsabilidad, marcando así con su irreductible personalidad aun más la actividad del grupo y su manifestación en la

70 Colectivo, "Ouvrez les prisons licenciez les armes”, La Révolution surréaliste, nº 2, enero 1925, p. 19.

${ }^{71}$ M.-C. BANCQUART, Op. cit. p. vi. 
revista. 1925: Fin de l'ére Chrétienne tiene por título este fascículo caracterizado por la fascinación del oriente y por la revuelta, y todo ello, tocado por el sombrío misticismo de Artaud. Misticismo y revuelta. Robert Desnos, muy activo en este no 3 de LRS, titula una parte de su Description d'une révolte prochaine, "La Revolución, es decir, el Terror": "Es la instauración de este lo que me interesa y solamente su llegada hoy, me permite aún esperar la desaparición de los canallas que estorban la vida." Para terminar en mayúsculas su texto: "Que ha llegado por fin el tiempo de ocuparse de la eternidad"72.

Artaud, que bien podría haber suscrito esas consignas, sobrevuela el tono de las intervenciones de esta peculiar entrega, pero su presencia se concreta, aunque sin firma, desde la presentación editorial del número. En $A$ Table, bajo la amenazante figura de un maniquí armado medievalmente con malla, casco y gran hacha, se presenta su visión mesiánica y arcana del surrealismo: "Abandonad las cavernas del ser. Venid. El espíritu sopla fuera del espíritu. Llegó el tiempo de abandonar vuestros refugios. Ceded al Todo-Pensamiento. Lo maravilloso está en la raíz del espíritu"73. También Artaud en toda su dimensión místico-revolucionaria, aunque como antes sin firma expresa, en las cinco proclamas colectivas que, a modo de panfletos, contiene el número y que ilustran bien el tono exaltado de su peculiar visión surrealista: Adresse au Pape: "Papa exterior al alma, déjanos nadar en nuestros cuerpos, deja nuestras almas en nuestras almas, no tenemos necesidad de tu cuchillo de claridades"; Adresse au Dalai-Lama: "Somos tus muy fieles servidores, oh Gran Lama, danos, envíanos tus luces, en un lenguaje que nuestros contaminados espíritus de europeos puedan comprender"; además de tres cartas a instituciones como Lettre aux Recteurs des Universités Européennes: "Dentro de la estre-

72 R. DESNOS, "Description d'une révolte prochaine." La Révolution surréaliste, no 3 abril 1925, p. 26.

${ }^{73}$ Editorial (Artaud). "A table", La Révolution surréaliste, $\mathrm{n}=3$ abril 1925, p. 1 . cha cisterna que ustedes llaman 'Pensamiento', los rayos espirituales se pudren como la paja. (...) En el nombre mismo de su lógica, les decimos: La vida apesta, Señores"74. El fascículo, como estaba establecido, se cierra con la sección Bureau de Recherches, ahora sí firmada expresamente por Artaud, donde detalla los objetivos de su oficina en pos de la revolución surrealista: “Esta revolución pretende una desvalorización general de los valores, la depreciación del espíritu, la desmineralización de la evidencia, una confusión absoluta y renovada de las lenguas, el desequilibrio del pensamiento". Y también reflexiones personales acerca de qué pueda ser el surrealismo: "Se puede admitir hasta cierto punto una mística surrealista, un cierto orden de creencias que escapen a la razón ordinaria, (...) El surrealismo, más que creencias, funda un cierto orden de repulsiones. El surrealismo es, ante todo, un estado de espíritu, no preconiza recetas"75.

[Fig. 14] La revista de André Breton.Muy significativa y excepcionalmente, ni Breton ni Aragon tienen contribuciones en el "número Artaud" de LRS. La religión del surrealismo tanteada por Artaud así como su revuelta socialmente inconcreta, situaban la revista en terrenos proclives a vagas e inoperantes utopías, difícilmente integrables en un devenir revolucionario social e histórico. El mismo mes de abril, Breton cierra definitivamente el Bureau de Recherches surréalistes $\mathrm{y}$, decepcionado con ese $\mathrm{n}^{\mathrm{o}}$ 3, decide, exactamente como ocurriera con el no 4 de Littérature $2^{a}$ serie, asumir en solitario la dirección del órgano del grupo anunciándolo, también como entonces, solemnemente. Pourquoi je prends la direction de la Révolution surréaliste abre el $\mathrm{n}^{\mathrm{o}} 4$ de $L R S$ con reflexiones acerca de literatura y de la ascendencia del surrealismo en la sociedad, lugar donde claramente

\footnotetext{
${ }^{74}$ Colectivo (Artaud). Diversos Tracs aparecidos en: La Révolution surréaliste, n⿳ํㅡ 3 abril 1925.

75 A. ARTAUD, "Bureau de Recherches", La Révolution surréaliste, $\mathrm{n}^{-}$3, abril 1925, p. 31. Trad. Á. GONZÁLEZ y otros, Escritos de Arte de vanguardia, Madrid, 1999.
} 
debía anclarse: "De nuevo apelo a la convicción que todos nosotros compartimos aquí, a saber, que vivimos en pleno corazón de la sociedad moderna con un compromiso tan grave que justifica por nuestra parte todo lo excesivo". También una suave llamada al orden surrealista pidiendo "evitar por encima de todo la repetición de pequeños actos de sabotaje como los que ya se han producido en el seno de nuestra organización"76. A diferencia de otros momentos en los que Breton actuará muy bruscamente, esta "toma de posesión" ya definitiva de la $L R S$ procura limar susceptibilidades y así, Artaud y Desnos son mencionados en términos elogiosos. Aparentemente no hubo conflictos subsiguientes, al menos no inmediatamente.

[Figs. 12 a, 13 b, 14 b, c, 15 c, 19 c] El núcleo humano de la revista procede, como es sabido y hubo ocasión de comprobar, de la literatura. El compromiso de los artistas estaba aún por llegar. Veíamos que solo Boiffard y Malkine estaban entre los que hicieron "profesión de fe de surrealismo absoluto". Sin embargo, Ernst era ya un viejo compañero de viaje en Littérature, como también Man Ray; Arp, ubicuo dadaísta, tampoco fue un desconocido. Sus imágenes serán habituales desde el primer número. Pero a lo largo de la vida de la revista, y especialmente en su origen, la aducción de artistas al grupo se aceleró rápidamente. Masson y Miró están en el grupo desde finales de 1924, aunque ambos muy celosos de su independencia, participan ya en las primeras entregas: el primero tiene una presencia constante con un papel destacadísimo en el $n^{0} 3$ debido a Artaud, el segundo ilustrará asiduamente la revista desde su $\mathrm{n}^{-}$4, fascículo en él también publica Pierre Roy. Tanguy, en el grupo desde diciembre de 1925, publica con gran proyección a partir del n으. 7. Aunque su participación activa aún tardará, Magritte y Giacometti se vinculan al grupo hacia 1927, como hará algo después Dalí, cuyas pintu-

${ }^{76}$ A. BRETON, "Pourquoi je prends la direction de la Révolution surréaliste." La Révolution surréaliste, ํㅡ 4, julio 1925 (pp. 1-3), p. 3. ras abundan en la última entrega de la revista. G. de Chirico, de mayor edad y reconocido ya por su obra anterior a la guerra, es asimilado al surrealismo con un estatus diferenciado. Auténtico Lautreamont en la pintura y revelación iniciática para muchos de los artistas ya citados, aparece en las fotografías de grupo que inauguran $L R S$ y es el único artista presente en todas sus entregas, también con textos hasta el no 5 . Pero lo está como artista "póstumo", su deslizamiento hacia el clasicismo (1925) irritará al grupo siempre maravillado con su primera manera. El artista vivo es relegado al ostracismo: en 1928 se le organiza una exposición en la Galerie Surréaliste en la que, contra la voluntad del artista, solo el período metafísico está presente. Picasso y Paul Klee son también referentes máximos del surrealismo artístico en LRS; Picasso -cuyo clasicismo no fue anatemizado- está presente en prácticamente todas las entregas. Sin que esta relación sea en absoluto completa, se ha tratado de ilustrar que la voluntad de integrar el arte en el discurso del surrealismo fue, por encima de discusiones a las que a continuación atenderé, implícitamente resuelta a su favor desde la propia concepción de la revista.

\section{EL SURREALISMO Y LA PINTURA}

La toma de la dirección por parte de Breton respondía, además de a enderezar la deriva mística aludida, a otro asunto igualmente desencadenado en el $\mathrm{n}^{-} 3$ de LRS. Desde el comienzo del proyecto, Max Morise y Pierre Naville se mostraron especialmente reticentes, a la integración del arte en la revista. En Beaux-Arts, una sección irónica de $L R S$ creada por el primero, Naville pone expresamente en duda la posibilidad y la conveniencia de una pintura surrealista: "Nadie ignora ya que no hay pintura surrealista. $\mathrm{Ni}$ los trazos de lápiz librados al azar de los gestos, ni la imagen que reconstruye las figuras del sueño, ni las fantasías imaginativas, está claro que no pueden ser así calificados. / Lo que hay son espectáculos. / La memoria y el placer de los ojos: ahí reside toda la estética. / Pensad que, de esta manera, el espíritu 
queda conminado a no admitir sino figuras invariablemente rectangulares: las esquinas, los bordes de un cuadro, el equilibrio, la altura y la anchura, etc...."77 En el breve texto al que pertenece esta cita se incide aún más en las limitaciones de las artes plásticas frente a la libertad de la literatura, proclamando en cambio la dimensión maravillosa del cine o de la fotografía que muestra "ampollas del mundo" desde las páginas de los periódicos. La visión de Naville se explica indudablemente en su contexto literario, el antes identificado. No es el caso de Breton que, atento a los desencadenantes antiliterarios, siempre halló en la imagen, después en el objeto, magnéticas fijaciones de lo real irreductibles al discurso, y en el arte una fascinante posibilidad de sobrevolar las convenciones, de crear lenguas adecuadas a lo indecible. Así pues, en la polémica iniciada por Pierre Naville, Breton tercia inequívocamente en favor de la integración de las prácticas artísticas en la actividad surrealista. La primera exposición surrealista de grupo, celebrada en otoño de 1925 en la importante Galerie Pierre, o la apertura algunos meses después de su Galerie Surréaliste con una exposición de Man Ray y de objetos oceánicos, así como la invención del frottage por Max Ernst o la práctica del Cadavre exquis durante esos mismos meses, avalan esta rápida integración. Así pues, muchas iniciativas habían situado ya a la práctica artística en primera línea y el gran dibujo mediumnímico que sirve de frontispicio a la presentación de Breton como director en Pouquoi je prends la direction..., parece sancionar tal ampliación del campo surrealista.

[Fig. 14, c] La importancia dada por Breton a esta ampliación se hará expresa a raíz de la objeción de Naville. Le surréalisme et la peinture ${ }^{78}$, uno de sus textos más difun-

${ }_{77}$ P. NAVILLE, "Beaux-Arts", La Révolution surréaliste, ํㅜㄴ 3, abril 1925, p. 27.

78 Aparece en LRS a lo largo de cuatro entregas entre julio de 1925 y octubre de 1927. Posteriormente, se publica como libro profusamente ilustrado: A. BRETON, Le surréalisme et la peinture, NRF/Gallimard, París 1928. didos, aparece ya en ese su primer número como director; después se completarán tres entregas más en los $n^{\text {os }}$ 6, 7 y 9-10. Ya en sus primeras célebres líneas, Breton afirma lo visible como lo inevitable y lo más inmediato: "El ojo existe en su estado primitivo. Las maravillas de la tierra a trescientos metros de altura, las maravillas del mar a trescientos metros de profundidad, tienen por testigo al ojo salvaje" ${ }^{\prime 79}$, sin embargo, continúa, el arte es esclavo de la imitación y con ello se aleja de sus extraordinarias posibilidades respecto a lo real. Para recuperar ese real maravilloso hay que buscar, imitar, "el modelo interior". Picasso, afirma Breton in extenso e ilustrando únicamente con su pintura el artículo, lo hizo en solitario hacía 15 años y continúa asombrando con su inaudita materialización de las recónditas realidades de la fantasía, con su verdadera ampliación de los territorios de lo real por encima de lo simplemente posible: "le revindicamos enfáticamente como uno de los nuestros, incluso cuando es imposible, y sería por lo demás desfachatado, pretender adaptar sus métodos al riguroso sistema de crítica que nos proponemos instituir" ${ }^{\prime 80}$. A través de Picasso la pintura adquiere carta de naturaleza dentro de la investigación surrealista, las artes plásticas quedan en libertad para establecer sus propios métodos e instrumentos y su participación no tendrá que estar sometida a criterios creados para el lenguaje literario. Breton lanza en su manifiesto a favor de la pintura un renovado $U t$ pictura poesis que supondrá la integración plena de los artistas al grupo -en un régimen, por cierto, menos fiscalizado que el de sus colegas poetas- y el reconocimiento del arte como una de las plataformas más efectivas de la acción surrealista.

[Fig. 15 a] Clarté. La revuelta y/o la poesía.- En su reconducción ideológica del cada vez más heterogéneo grupo y de su revista, le quedaba aun a Breton otro campo por resituar, el de la "revuelta", la dimen-

\footnotetext{
${ }^{79}$ A. BRETON, "Le surréalisme et la peinture", La Révolution surréaliste, no 4, julio 1925, p. 26.

${ }^{80}$ Ibid. p. 30.
} 
sión efectivamente revolucionaria de la acción colectiva surrealista. La gran influencia de Artaud -“"Tenemos menos necesidad de adeptos activos que de adeptos conmovidos (bouleversés)" 81 - en los números anteriores se manifestó, como hemos visto, en un espiritualismo radical fascinado con el orientalismo y a menudo con la muerte. Breton reconduce hacia efectos más positivos estas energías, limita el placer de la crispación, afirma el arte y la poesía y, lo que ahora nos interesa, introduce un sesgo de compromiso político expreso que marcará para siempre al grupo. La primera manifestación práctica de tal deriva fue su aproximación a lo largo de 1925 al grupo vinculado a Clarté (1921-1928) una revista marxista de reflexión política vinculada a las ideas de la Tercera Internacional, con la que se establecerá una intensa colaboración recíproca. El no 5 de octubre de 1925 , acoge un momento importante para la evolución política de Breton: su lectura de Lenin de León Trotsky de la que da cumplida y admirada cuenta en Chroniques y también, cerrando ya el fascículo, la formalización de la citada colaboración entre LRS y Clarté, junto a otras publicaciones. Se trata de $L a$ Révolution d'abord et toujours! un manifiesto político que exige el desarme, se opone a la Guerra de Marruecos, niega el patriotismo -"para nosotros Francia no existe" - y ensalza la revolución: "Somos la revuelta del espíritu; consideramos la Revolución sangrante como la venganza ineluctable del espíritu humillado por vuestras obras. No somos utopistas: solo concebimos esta Revolución bajo su forma social" ${ }^{\prime 2}$. El grupo surrealista prácticamente al completo, además de algunos antiguos dadaístas, junto a Clarté y otros grupos lo firman.

Las entregas de 1926 de $L R S, \mathrm{n}^{\text {os }}$ 6, 7 y 8 , contendrán este matiz político a través de colaboraciones procedentes de Clarté y del

\footnotetext{
81 A. ARTAUD, aforismo aparecido en La Révolution surréaliste, nº 3, abril 1925, p. 13.

${ }^{82}$ Colectivo, "La Révolution d'abord et toujours!", La Révolution surréaliste, no 5, octubre 1925 (pp. 31-32), p. 32.
}

propio grupo surrealista: Aragon, Massot o Naville, pero sin por ello cambiar esencialmente el tono extremado, altamente poético y experimental de la publicación surrealista. La cuestión del grado de militancia en estructuras políticas de partido surge inevitablemente, generando fuertes tensiones que Breton intentará centrar estableciendo compromisos, pero al mismo tiempo evitando dependencias que mermen la autonomía de las investigaciones surrealistas. Así lo establece en Légitime défense, uno de sus más ambiciosos textos políticos, surgido como contestación a La Révolution et les Intellectuels (Que peuvent faire les surréalistes), un nuevo texto polémico de Pierre Naville. Desde su militancia en el Partido comunista francés, PCF, y su dirección efectiva de Clarté, Naville se esforzaba por atraer a sus compañeros surrealistas hacia la ortodoxia de partido invitándoles a "abandonar sus juegos idealistas". Breton responde: "Afirmo que la llama revolucionaria brilla donde ella quiere y que, en el período de espera en que vivimos, no corresponde a un reducido número de personas decretar que sea aquí o allá donde únicamente deba brillar. (...) En el terreno de los hechos, ningún equívoco por nuestra parte: nadie hay entre nosotros que no desee el tránsito del poder de manos de la burguesía a las del proletariado. En espera de ello, no deja de ser menos necesario que las experiencias de la vida interior prosigan y ello, por supuesto, sin control exterior, incluido el marxista" ${ }^{83}$.

[Fig. 15 b, c] Con revisar someramente el mismo $\mathrm{n}^{\mathrm{o}} 8$ de la revista que contiene Légitime défense, se aprecia hasta qué punto la libertad poética de $L R S$ no sufrió, ni en estos momentos de compromiso, menoscabo alguno. Artaud tiene una participación notable: redescubre para el surrealismo al misterioso Paolo Uccello y da a conocer Lettre à la voyante-dedicado a Breton y su Lettre aux voyantes del $\mathrm{n}^{\mathrm{0}} 5$-, dispuesto junto a una gran reproducción de La Vierge corrigeant l'Enfant-

${ }^{83}$ A. BRETON, "Légitime défense", La Révolution surréaliste, no 8, diciembre 1926 (pp. 30-36), p. 32. 
Jesus devant trois témoins de Max Ernst. La iglesia está presente también en la imagen Notre collaborateur Benjamín Péret injuriant un préte, ya arriba citada. Un análisis perturbador de la sociedad en Revue de presse aporta noticias de suicidios y otros sucesos tan luctuosos como desquiciados que se mezclan con ataques a Mussolini. Poemas y textos surrealistas. Etc.

El rechazo a cualquier control externo al surrealismo afirmado por Breton, no variaba su exigencia de compromiso político expreso. Y esto por consideraciones ideológicas específicas acerca del propio sentido vital del surrealismo como actividad necesariamente revolucionaria, pero también porque tal militancia constituía al mismo tiempo el mejor antídoto contra las evanescencias espiritualistas y estéticas en las que tan fácilmente podía verse envuelta la actividad del grupo. Las simpatías previas por un marxismoleninismo transmitido a través de Trotsky y la toma de partido de los intelectuales ante la Guerra de Marruecos, generan un debate acerca de la conveniencia de militar en el PCF. Antonin Artaud, Phillippe Soupault y Roger Vitrac rechazaron cualquier compromiso exterior y en la asamblea celebrada en noviembre de 1926 en el café Le Prophète son excluidos del grupo a lo que el primero responderá con el conocido, À la grande nuit ou le Bluff surréaliste ${ }^{84}$, donde, quien en su momento fuera gran contrapeso de Breton, pone de manifiesto el abismo que les separaba. Masson, Limbour y otros también se alejan. Es la primera crisis efectiva de la era propiamente surrealista que es respondida por la plana mayor: Breton, Aragon, Éluard, Péret, Unik, con su inscripción en el PCF.

[Fig. 16] Clarté, recíprocamente infiltrada de surrealismo -como es notable, por ejemplo, en su salida de junio de 1926: Aragon, Péret, Éluard o Leiris colaboran-, ve cómo sus lectores atónitos se alejan y recupera su univocidad política. Por su parte, $\mathrm{La}$ Révolutión surréaliste se resiente igualmente,

84 A. ARTAUD, A la grande nuit ou le Bluff surréaliste, Edición: Chez l'auteur, París, 1927. logrando sacar una sola entrega a lo largo de 1927, el no doble 9-10 del mes de octubre y otra a lo largo de 1928, el no 11 del mes de marzo. Son entregas en las que lo políticamente expreso cede, iniciándose una etapa de gracia, profundamente surrealista de la revista, caracterizada por sus investigaciones y encuestas acerca de la sexualidad o el amor, por su interés renovado hacia la mujer y el deseo; con una igualmente renovada dedicación a los sueños, el cadáver exquisito y la escritura automática; L'ecriture automatique, título precisamente de la entrega de 1927. Destaca igualmente, la presencia de Freud y el psicoanálisis o de sus precedentes clínicos, rememorando los estudios sobre la histeria desarrollados por Charcot en la Salpêtrière, con las ahora célebres fotografías de Agustine debidas a Régnard, También las primeras manifestaciones de la creciente importancia que se concederá a la dialéctica hegeliana.

\section{SEVERIDAD ABSOLUTA, OCULTACIÓN VERDADERA}

[Figs. 17, 18 a] Variétés y Le surréalisme en 1929.- Como órgano grupal y de escaso éxito comercial, $L R S$ se financiaba con las aportaciones del propio colectivo, por lo que su periodicidad era en realidad muy variable. El undécimo número de la serie sale en marzo de 1928 y la carencia de fondos para la siguiente entrega frustra su edición cuando su contenido estaba ya bien configurado. Es entonces cuando desde el importante entorno surrealista belga, muy vinculado ya al grupo de París, surge la posibilidad de mediar ante Paul Gustav Van Hecke, editor de la revista magazine Variétés y galerista bien relacionado con los surrealistas de Bruselas, con el fin de promover la edición del material ya preparado. El acuerdo no tardaría en llegar pues existían fuertes sinergias intelectuales y profesionales entre una y otra parte; en lo relativo a la financiación, una parte fue sufragada desde París con lo obtenido de 1929, un libro clandestino compuesto por textos eróticos de Aragon y Péret ilustrados con fotografías del mismo tono y 
bien explícitas de Man Ray ${ }^{85}$. Algunos documentos de este acuerdo como la carta enviada por Breton dando instrucciones muy específicas y técnicas acerca del material a editar, textos y clichés, permiten apreciar hasta qué punto aquellos intelectuales eran expertos en la actividad editorial ${ }^{86}$.

En junio de 1929 aparece, pues, un número especial de Variétés, número fuera de la serie ordinaria titulado Le surréalisme en $1929^{87}$. Conserva todos los aspectos formales y visuales característicos de la revista bruselense -que se editaba en cuarto, con cuadernillos separados en papel cuché para las abundantes secciones de imagen-, aunque con la significativa variación del color de su orla estrellada que pasa del azul al rojo, tan querido por los surrealistas. Sin embargo, en lo relativo al contenido, y aun considerando la importante participación pactada de integrantes del surrealismo local, se trata a todos los efectos de un nuevo fascículo de revista del colectivo surrealista, coordinado, de hecho, por el propio Breton, y no de los menos relevantes dentro de la historia del grupo. No obstante los destacables contenidos textuales y la especialmente interesante y abundante contribución artística y de imagen -citar, por ejemplo, la doble página Le cadavre exquis por Miró, Morise, Man Ray y Tanguy o la primicia de la Femme 100 Têtes de Ernst-, me centraré en lo que hace de Le surréalisme en 1929 un documento importante desde el punto de vista del devenir del grupo surrealista.

${ }^{85} \mathrm{Ph}$. DEWOLF, De la mascotte au cadavre, pp. 7-8. En: Le Surréalisme en 1929, Bruselas, 1994. Existe una reedición actual de la autoedición de 1929: B. PÉRET, L. ARAGON, MAN RAY, 1929, París, 2004.

${ }^{86}$ Esta carta, así como otros detalles relacionados con la gestación de Le surréalisme en 1929, se halla en el texto de Ph. Dewolf citado.

87 Variétés. Subtítulo: Revue mensuelle illustrée de l'esprit comtemporain. Revista cultural y mundana de tendencia moderna. Editada en Bruselas por P. G. van Hecke (director) entre 1928 y 1930. Reimpresión facsímil: Variétés. Le Surréalisme en 1929, Didier Devillez Editeur, Bruselas, 1994, introducción Philippe Dewolf.
[Fig. 17 b] A suivre.- En febrero de 1929 el núcleo del grupo surrealista se dirige mediante carta abierta a un amplio entorno de personas que, por encima de antagonismos conocidos, pudieran compartir con el los un denominador común. Tras presentar una situación desoladora en la que nada se logra por falta de una acción común -“(las revistas) La Lutte de Classes, Le Grand Jeu, Distances, L'Esprit, La Révolution surréaliste, etc. ya no aparecen"- y recordar momentos destacados de acción de grupo pero también de confrontación (Congreso de París, Un cadáver (A. France), Carta a P. Claudel, expulsión de Artaud y Soupault, colaboración con Clarté y otros grupos revolucionarios, etc.) se les pide que definan su disposición a participar en una acción unitaria y comprometida contra el enemigo común respondiendo algunas preguntas. Recibidas las respuestas, todos los concernidos son convocados el 11 de marzo en el Bar du Chateau: "Le ha sido concedida la palabra a Raymond Queneau que presenta las respuestas a la carta del 12 de febrero clasificándolas según sus conclusiones, contra o por una acción común: 4 contra, 4 pro o contra con reservas, 36 pro. Se da lectura in extenso a todas las respuestas" ${ }^{\prime \prime 8}$. Tras esta reunión, de nuevo como si se estuviera levantando acta de un proceso, Breton y Aragón se encargan de anotar cada respuesta y de comentarlas de forma muy crítica, incluyendo ocasionalmente el insulto y la descalificación. Se añaden otras cartas, réplicas y contrarréplicas hasta confeccionar un extenso documento titulado A suivre ${ }^{89}$, “Continuará. Pequeña contribución al dossier de algunos intelectuales de tendencias revolucionarias (París 1929)". Es precisamente este documento A suivre, numerado a parte y en páginas rojas, lo que abre $L e$ surréalisme en 1929, Breton se ocupa personalmente ante los editores de cómo deben disponerse sus 34 páginas, insistiendo en la rápida salida del fascículo, "todo está ya

${ }^{88}$ L. ARAGON, A. BRETON, "A suivre", Variétés. Le Surréalisme en 1929, junio 1929, p. IX.

${ }^{89}$ Ibid., p. i-xxxii. 
listo para aparecer muy, muy deprisa", escribe al editor en mayo ${ }^{90}$, urgencia que está en relación con su interés por hacer público el debate así como la opinión oficial de su grupo, y la suya propia, acerca del mismo. Como en otras ocasiones, lo que piden y exigen Breton y Aragón es compromiso con una acción común, aunque sin concretar en este caso su plataforma de desarrollo. Y lo que se comprueba en las respuestas, a pesar de los 36 pro, es un cambio escenario, la escasa predisposición: de unos a aceptar nuevamente la disciplina del surrealismo, de otros a implicarse nuevamente en una acción de partido. La publicación de $A$ suivre en Variétés certificó, en definitiva, el desinterés por una acción revolucionaria común incluso entre grupos de evidente sinergia con la sensibilidad surrealista, como eran especialmente los de Documents y Le Grand Jeu.

[Figs. 17 c, 18] Valdría la pena ahora tener espacio para extenderse sobre los contenidos del número surrealista de Variétés y, desde luego, para recuperar la fascinante publicación de Van Hecke, un gran testigo de su época entre el humor y el compromiso, entre la burguesía ilustrada y la vanguardia, entre la fascinación por el glamour moderno y la admiración por la Unión Soviética ${ }^{91}$. Respecto a Variétés en general, subtitulada "Revista mensual ilustrada del espíritu contemporáneo", solo decir que fue plataforma de los mejores fotógrafos del momento haciendo un uso discursivo autónomo de la imagen que servirá de ejemplo a revistas parisinas como Bifur, Documents o la misma Le surréalisme au service de la Révolution. Son particularmente memorables sus números especiales dedicados a África y a la URSS. En cuanto a Le surréalisme en 1929, es inevitable detenerse en su más célebre documento, el mapamundi de Le monde au temps

${ }^{90} \mathrm{Ph}$. DEWOLF, De la mascotte au cadavre, Op. cit., p. 8 .

91 "Variétés, por la imagen y por el texto refleja todas las cosas de la vida que interesan a los hombres y a las mujeres que desean ser de su tiempo" reza su autopromoción. Para más detalle: J. MAÑERO, París 1919-1939. Escultura, crítica y revistas de arte, Op. cit., pp. 172-176. des surréalistes ${ }^{92}$, por el que Breton mostró un especial interés ante el editor. Se trata de un mapa subjetivo donde el tamaño de los territorios es directamente proporcional al interés que despiertan en el grupo: Europa o Estados Unidos apenas existen, sin embargo Alaska, Nueva Guinea o la Isla de Pascua, son enormes, su arte lo es; la URSS mantiene su ya de por sí gran tamaño pues se trata de la patria de la revolución, también Méjico. Y solo dos ciudades, Paris capital del surrealismo y Constantinopla donde en ese momento reside exilado Trotsky, el profeta de la revolución permanente, al que el grupo entroniza en una de las páginas del número situando su imagen a pie de igualdad junto a la de Freud, con cuyo texto L'humour se abría Le surréalisme en 1929.

[Fig. 19] Todavía, La Révolution surréaliste.- Trotsky y Freud. El discurso del Seconde manifeste du surréalisme no puede estar mejor sugerido. Tras el remarcable episodio de Variétés el grupo recupera La Révolution surréaliste cuyo último número, 12 de la serie, sale el 15 de diciembre de 1929. Para entonces Documents (1929-1930) ${ }^{93}$, la revista entre artística y etnográfica animada por Georges Bataille, iba por su séptimo y deslumbrante número y se había convertido en un polo de atracción para algunos destacados miembros del surrealismo que se convirtieron en colaboradores habituales y parte de la publicación. Aunque muchos de ellos rehusaron contestar a A suivre, Bataille y Michel Leiris -que tan gran papel jugó en LRS- sí lo hicieron, además de André Masson, los tres negativamente. "Ya está bien de idealistas coñazo (emmerdeurs)" contesta concisamente Bataille mientras que Leiris se muestra más sibilino: "La política de unión sagrada no me dice nada que valga, y siempre he tenido,

${ }^{92} \mathrm{XXX}$, "Le monde au temps des surréalistes", Variétés. Le surréalisme en 1929, junio 1929, pp. 26-27.

93 Documents. Archéologie. Beaux-Arts, Ethnographie, Variétés. Editada en París con periodicidad mensual, 15 números entre 1929 y 1930. Formato: 21 x 27 cm. Dirección efectiva de Georges Bataille. Reimpresión Documents $n^{\circ} 1$ à 7, 1929 et $n^{\circ} 1$ à 8, 1930; Editions JeanMichel Place, Paris, 1991. 
por encima de todo, horror a las chapuzas. Tomen esto, si les parece, por una respuesta a su cuestionario" ${ }^{\prime 94}$. Breton se tomará estas respuestas como algo más que simples salidas de tono y reservará la parte más agria e intransigente de un nuevo manifiesto para responder a la desafección del grupo asimilado a Documents.

Quelle sorte d'espoir mettez-vous dans l'amour? Tal es el título que, asociado a un vigoroso rayo sobre un cielo nocturno, recibe ese último número, único de 1929, de LRS. El rayo ilustra bien la Enquête sur l'amour cuyas respuestas contiene el fascículo, pues solo el amor se le puede comparar, pero también el traumático efecto que producirá en el surrealismo el Seconde manifeste du surréalisme con que Breton lo inicia, pues supuso un antes y un después. Como ocurriera con aquel "desmoralizante" último número de Littérature, el presente de LRS es la constatación de un fin de ciclo. El grupo surrealista presencia el abandono de componentes históricos como Naville o, nuevamente tras una breve reconciliación, Artaud. También, cómo el surrealismo manifestado en grupos jóvenes como Le Grand Jeu, prefiere una celosa autonomía antes que la acción común. $\mathrm{Y}$, sobre todo, asiste impotente al citado trasbase de energías surrealistas a Documents. Por ello, la defraudada solicitud de colaboración colectiva demandada en $A$ suivre, se convierte ahora con el siguiente texto programático publicado íntegramente en esta última entrega de $L R S$, el Second manifeste $d u$ surréalisme $e^{95}$, en exigencia muy concreta de adscripción total y en aviso contra desviaciones. Y ello, en forma de compromiso revolucionario tanto estético como político, al lado de las revoluciones sociales reales. Breton, a través este su nuevo manifiesto, toma ahora verdaderamente el mando, única vía, entiende, para refundar el surrealismo concretando su función dentro del espacio social: la revolución poética solo es posible

\footnotetext{
94 "A suivre", Op. cit., p. IX.

${ }^{95}$ A. BRETON, "Seconde manifeste du surréalisme", La Révolution surréaliste, n⿳0 12, diciembre 1929 (pp. 1-17)
}

inserta en la revolución social, hay pues que ponerse al servicio de la revolución, tal como rezará el título de la próxima revista del grupo. Lo cierto es que Breton, cuyo protagonismo en el proceso que ahora se describe es absoluto, se estaba anticipando a la complejidad e intensidad política de la década a punto de comenzar, algo que incluso el propio Bataille reconocerá implícitamente más tarde al justificar parcialmente la fuerte autoridad ejercida por el poeta ${ }^{96}$.

[Fig. 19 b] Segundo manifiesto del surrealismo.- "El acto surrealista más puro consiste en bajar a la calle, revólver en mano, y disparar al azar, mientras a uno le dejen, contra la multitud. Quien no haya tenido, por lo menos una vez, el deseo de acabar de esta manera con el despreciable sistema de envilecimiento y cretinización imperante, merece un sitio entre la multitud, merece tener el vientre a tiro de revólver" ${ }^{\prime 97}$. En el Second manifeste la poesía surrealista se ejerce en el mundo, entre la multitud, la intensidad es la misma así como lo extremado de la intención, pero su dimensión revolucionaria consiste en hacerla efectiva pues "todo está aún por hacer, todos los medios son buenos para aniquilar las ideas de familia, patria y religión". Para llevar finalmente a cabo tales tareas pendientes hay que enraizar el surrealismo en la dialéctica hegeliana y en

\footnotetext{
96 "Hoy estoy inclinado a creer que las exigencias de Breton que acabaron en la ruptura generalizada de los años 1928-1929, estaban en el fondo justificadas, había en Breton un deseo de consagración común a una misma verdad soberana, un odio a toda concesión, en cuanto que se trataba de esa verdad de la que quería que sus amigos fueran la expresión, so pena de no ser más sus amigos; son las exigencias con las que todavía estoy de acuerdo. Pero Breton se equivocó al atenerse estrechamente a las formas exteriores de esa fidelidad, una desgracia tanto mayor cuanto que, contando con una suerte de prestigio hipnótico -una autoridad inmediata excepcional-, hizo uso de ello sin gran reserva, sin una verdadera prudencia." G. BATAILLE, Le Pont de l'Epée, no 41, octubre 1969, pp. 143-145, en J. PIERRE, Tracts surréalistes et declarations collectives, París, 1980.

${ }_{97}$ A. BRETON, "Second manifeste du surréalisme", Op. cit., p. 2. Traducción: A. BRETON, Manifiestos del surrealismo, (trad. Andrés Bosch), Madrid, 2002
} 
el materialismo histórico, para, a continuación, aproximarse comprometidamente a la acción revolucionaria, concretamente -como antaño- al PCF y ello a sabiendas de las dificultades reales que tal asociación conlleva. Sin embargo, poco importan las inevitables incomprensiones del socialismo político si, a través de sus estructuras el grupo surrealista tiene ocasión de hacer efectiva su simpatía por la "masa" pues al fin y al cabo la revolución social es un objetivo compartido ${ }^{98}$.

Pero, según Breton, para dar este nuevo y necesario rumbo a la acción del grupo, hay que recapitular lo hecho, "saber qué clase de virtudes morales cultiva el surrealismo" para, a continuación, proceder a la verificación de su cumplimiento. Con este objetivo Breton se erige en juez inapelable y pide cuentas a cada uno de lo hecho y de sus desviaciones, redactando un extenso texto violentamente recriminatorio hacia grupos y personas concretas del entono surrealista. Pues por encima de amistades y antiguas camaraderías está el cumplimiento de las promesas revolucionarias, "el surrealismo no puede quedar a merced del humor de los hombres de tal o cual clase". Breton parece apelar siempre a la acción colectiva pues no hay hombre ni obra libre de equívocos. $\mathrm{Ni}$ Rimbaud -antes "surrealista en todo"-, ni Baudelaire, ni Poe -culpable de regalar al mundo un método policiaco-, ni tan siquiera Sade -contrarrevolucionario en la Convención-, todos fueron en algún grado negligentes al no prevenir el uso pernicioso que de su obra se haría, "Con la sola excepción de Lautréamont, todos han dejado tras de sí rastros equívocos" ${ }^{\prime 99}$. Y si esos grandes referentes de una visión libre y profunda de la vida erraron en alguna medida, ¿qué decir de las debilidades de tantos allegados al surrealis-

98 "'Si es marxista no tiene ninguna necesidad de ser surrealista' se le dice a uno de los nuestros (...) Me pidieron que presentara a la 'célula del gas' un informe sobre la situación en Italia, y especificaron que únicamente podía basarme en realidades estadísticas (producción de acero, etc.), y que debía evitar ante todo las cuestiones ideológicas. No pude hacerlo." Ibid., p. 6.

${ }^{99}$ Ibid., p. 2 mo? Algunos, entre los más destacados activistas de primera hora, nombrados entre los juramentados del primer manifiesto, hacía tiempo que habían sido juzgados y expulsados del grupo, en la asamblea, ya citada, del café Le Prophète, nada más quiere saber de ellos, afirma Breton, sin embargo, "El primero de los mencionados señores (Artaud) cometió la imprudencia de quejarse y, ahora, me parece oportuno volver a ocuparme de su caso"100. Ciertamente se ocupa y lo hace como quien quisiera asegurarse de dejar las cosas sin opción alguna de reconciliación: un cretino dentro de un equipo de destajistas "a tanto la línea. MIERDA". En cuanto a Soupault, anuncia sus inminentes acusaciones debidamente: y con él llegamos a la "infamia total".

Es cierto que en ocasiones Breton justifica sus invectivas alegando ataques personales previos -es el caso de los dos anteriores- pero indudablemente la razón de fondo de la llamada al orden, al orden surrealista, ciertamente, es el proceso de disolución que para el grupo está suponiendo la diversificación de actividades de sus ya muy prestigiosos componentes $\mathrm{y}$, en todo caso, el relajamiento de la tensión que inicialmente motivó al grupo; a Duchamp, en este caso con mucho tacto y respeto, le recuerda que no debería abandonar la verdadera partida por una de ajedrez. Así, mientras muestra de nuevo su simpatía por los intelectuales marxistas de la revista Clarté, detesta toda colaboración con la activa y ciertamente fascinante revista literaria y artística Bifur (1929-1930) ${ }^{101}$, al tiempo que reconviene una

\footnotetext{
100 En referencia al texto de Artaud, A la grande nuit ou le Bluff surréaliste. Ibid., p. 3

101 Bifur. Revista de vanguardia literaria y artística (fotografía principalmente) con 8 números editados en París entre 1929 y 1930 . Formato 19 x $24 \mathrm{~cm}$. Dirigida por Georges Ribemont-Dessaignes. Con contribuciones de: Gottfried Benn, Brassaï, Claude Cahun, Robert Desnos, Max Ernst, Ramón Gómez de la Serna, James Joyce, Fernand Léger, Michel Leiris, André Masson, Henri Michaux, Tina Modotti, Pascal Pia, Francis Picabia, Boris Pilniak, Man Ray, Rabindranath Tagore, Tristan Tzara, William C. William, entre otros. Reimpresión: Bifur $n^{\circ}$
} 
vez más al joven grupo artístico-literario de la revista LeGrand Jeu (1928-1930) ${ }^{102}$ a fundirse en un proyecto común. Pero el caso más grave para la reconstitución del grupo es, como quedó dicho, el de la hoy mítica revista Documents, son muchos y entre ellos algunos de los mejores, quienes se han situado en su entorno que es el de Bataille: “Dispuestos a tomar salida en la carrera que, como hemos visto, organiza M. Bataille, están los señores Desnos, Leiris, Limbour, Masson y Vitrac. (...) Creo que es extremadamente significativo ver que de nuevo se reúnen todos aquellos a quienes una tara $\mathrm{u}$ otra apartó de su primera actividad definida, ya que parece muy probable que tan solo tengan en común su resentimiento ${ }^{103}$.

Justo antes de este punto del Second manifeste, antes de concretar detalladamente un virulento ataque contra cada uno de los participantes en la "carrera organizada por Bataille", aparece, bien destacada, una frase llena de misterio, un suspense silencioso, previo a la catástrofe: "Exijo la ocultación profunda y verdadera del surrealismo". Lo contenido después en el manifiesto solo es furia -"En esta materia proclamo el derecho a la severidad absoluta"-; al igual que las consecuencias que desencadena. La más grave fue Un cadavre, un extenso panfleto, agresivo, burlesco y sin vuelta atrás, que sus antiguos compañeros ahora vinculados a Documents dirigieron de inmediato contra Breton. Este episodio consuma la ruptura del grupo, forzando una nueva etapa coincidente con la década que se inicia y dentro de la cual hallaría ya el marco de estudio adecuado.

1 à 8, 1929-1931, Editions Jean-Michel Place, Paris, 1976; con introducción de Jacqueline Leiner

${ }^{102}$ Le Grand Jeu, Revista de vanguardia literaria y artística. Editada en París, 3 números entre 1928 y 1930. Dirigida por René Daumal, Roger Vailland y Roger Gilbert-Lecomte. Otros colaboradores: Desnos, RibemontDessaignes, Vitrac, Gómez de la Serna, Sima, Masson, Harfaux, etc. Reimpresión: Le Grand Jeu, Editions JeanMichel Place, Paris, 1977.

103 A. BRETON, "Second manifeste du surréalisme", Op. cit., p. 16.
[Figs. 19 c, 20] Ojos cerrados, surrealismo oculto.- Volvamos ahora, para cerrar este recorrido por la primera década del surrealismo a través de sus revistas, a otros aspectos de esa última y compleja entrega de $L R S$ pues, junto al cierre de una etapa forzado por el Second manifeste, contiene ya algunos de los elementos humanos protagonistas de la renovación subsiguiente. Tras el frontispicio de rojas huellas de labios que preside el extenso Manifeste, solo una imagen lo ilustra, y ya tras la firma: La Guerre de G. de Chirico. Una significativa conclusión que en la página inmediata da paso a Les accommodations des Désirs la primera de las nada menos que cuatro reproducciones con que LRS acoge a Salvador Dalí. Dalí, que junto a Buñuel firma Un Chien Andalou, un completo guion del filme, fundamental para su interpretación; Buñuel puntualiza en su preámbulo que “'Un perro andaluz' no existiría si el surrealismo no existiera"104. La asociación al surrealismo de los jóvenes españoles es sin duda el gran e inesperado proyecto de futuro contenido en el fascículo. Menos inesperada es, tras la experiencia de Variétés y sus previos vínculos con el grupo, la primera participación de los belgas René Magritte y Albert Valentin en LRS. Magritte propone con su importante artículo gráfico Les mots et les images ${ }^{105}$, una anticipada visión del lenguaje como texto (Barthes). Valentin, uno de sus fotomontajes. Indudablemente el futuro está contenido entre estas páginas.

Dada la situación del grupo y el tono del nuevo manifiesto, califiqué a este último número de LRS de "desmoralizante", en alusión a su equivalente de Littérature. Desde una consideración global creo adecuado establecer tal paralelismo, sin embargo, no hay constancia -como si la hubo en el caso de Littérature- de que sus responsables considerasen finalizada la serie con esta entrega.

${ }^{104}$ L. BUÑUEL, S. DALÍ, "Un chien Andalou”, La Révolution surréaliste, n 12, diciembre 1929 (pp. 34-37), p. 35.

${ }^{105}$ R. MAGRITTE, “Les mots et les images", La Révolution surréaliste, $\mathrm{n}^{\mathrm{o}}$ 12, diciembre 1929 (pp. 32-33) 
Pero, haciendo honor a la percepción surrealista, hay que reparar en algunos síntomas, algunas simetrías que avalan la idea de círculo que se cierra. La revista se decide a incluir por vez primera el índice general con el que las revistas de tirada regular solían cerrar cada año o volumen, aunque, en su caso, toda la serie: Table des douze premiers numéros; tiempo cumplido, aunque también tiempo expectante. Igualmente un ciclo cumplido si relacionamos el extenso artículo Mobiles inconscients $d u$ suicide ${ }^{106}$, que trata científicamente el suicidio desde un punto de vista psicoanalítico, con aquella Enquête: Le suicide est-il une solution? cuyo interrogante abría el $n^{-} 1$ de la publicación; aunque ahora esa muerte compleja se trata a la luz de la ciencia de los sueños. Sueños, como en los que parecen estar sumidos los surrealistas -en la imagen que ahora comentaré- dispuestos alrededor de la idea de amor, idea presente ya en la frase de portada: “Qué clase de esperanza pone usted en el amor?". Esta es, precisamente, la primera de las preguntas que se responden en Enquête ${ }^{107}$, propuesta con la que se cierran los contenidos de $L R S$; y, de nuevo, una extraña simetría, ahora de formato investigador, con la encuesta sobre el suicidio del $n^{0} 1$. Entre la larga sucesión de páginas de Enquête solo dos imágenes. La primera, una pequeña fotografía perdida en la página de texto: una joven, volviendo la cabeza, mira con tal fijeza que apenas permite leer el texto circundante. La otra, última que aparece en la revista, es una de las más significativas y conocidas de $L R S$, verdadera síntesis del momento preciso que vive el grupo.

[Figs. 11c, 20] Je ne vois pas la... cachée dans la forêt $t^{108}$ es un fotomontaje en el que sus miembros, retratados en fotomatón -máqui-

${ }^{106}$ J. FROIS-WITTMANN, "Mobiles inconscients du suicide", La Révolution surréaliste, no 12, diciembre 1929 (pp. 41-44)

${ }^{107}$ Colectivo, "Enquête", La Révolution surréaliste, nº 12, diciembre 1929 (pp. 65-76)

${ }^{108}$ Imagen, "Je ne vois pas la... cachée dans la forêt", La Révolution surréaliste, no 12, diciembre 1929, p. 73. na presente en París desde 1928 que fascinó a los surrealistas-, y todos ellos con los ojos cerrados, se distribuyen alrededor de una pintura de Magritte, alrededor de una mujer desnuda que es parte un texto: "No veo la [mujer] oculta en el bosque". De nuevo una elipsis temporal que remite al comienzo, a 1924 y aquella otra tabla aparecida en el $n^{\circ}$ 1 en la que 28 surrealistas y allegados rodeaban a Germaine Berton, una mujer real y justiciera. Ahora, excluidos los anatemizados por el Manifeste, solo 16 surrealistas resistentes, o bien recientes, circundan a otra mujer, pero mujer-sueño -vuelta al inicio-, buscan una dimensión del amor solo imaginable con los ojos cerrados, pues, inevitablemente, se halla oculta: el surrealismo también, según Breton, exigía en ese momento crítico su propia "ocultación profunda y verdadera". Así, apelando, aunque mermados, a la acción colectiva y el compromiso militante propios del surrealismo, este nuevo retrato -que es su nuevo estado- les concentra en lo que para ellos siempre fue más real y compartido, el amor y sus representaciones. Y lo hace gráficamente, paradojas de un azar cargado de sentido, bajo la sutil presidencia de André Breton, cuya posición en el lugar central del borde superior de la tabla de retratos deriva mágica y naturalmente del orden alfabético de su distribución. El despertar de este nuevo sueño inducido colectivo alrededor de la mujer, será brusco y tendrá lugar ya concluida una época, un année mental, tal como Aragón caracterizó a LRS en Introduction a 1930: "Este artículo está escrito para el no 12 de La Revolución surrealista que concluye así una suerte de año mental que ha durado un lustro" ${ }^{\prime 109}$.

${ }^{109}$ L. ARAGON, "Introduction a 1930", La Révolution surréaliste, $\mathrm{n}^{\circ}$ 12, diciembre 1929 (pp. 57-64), p. 62. 

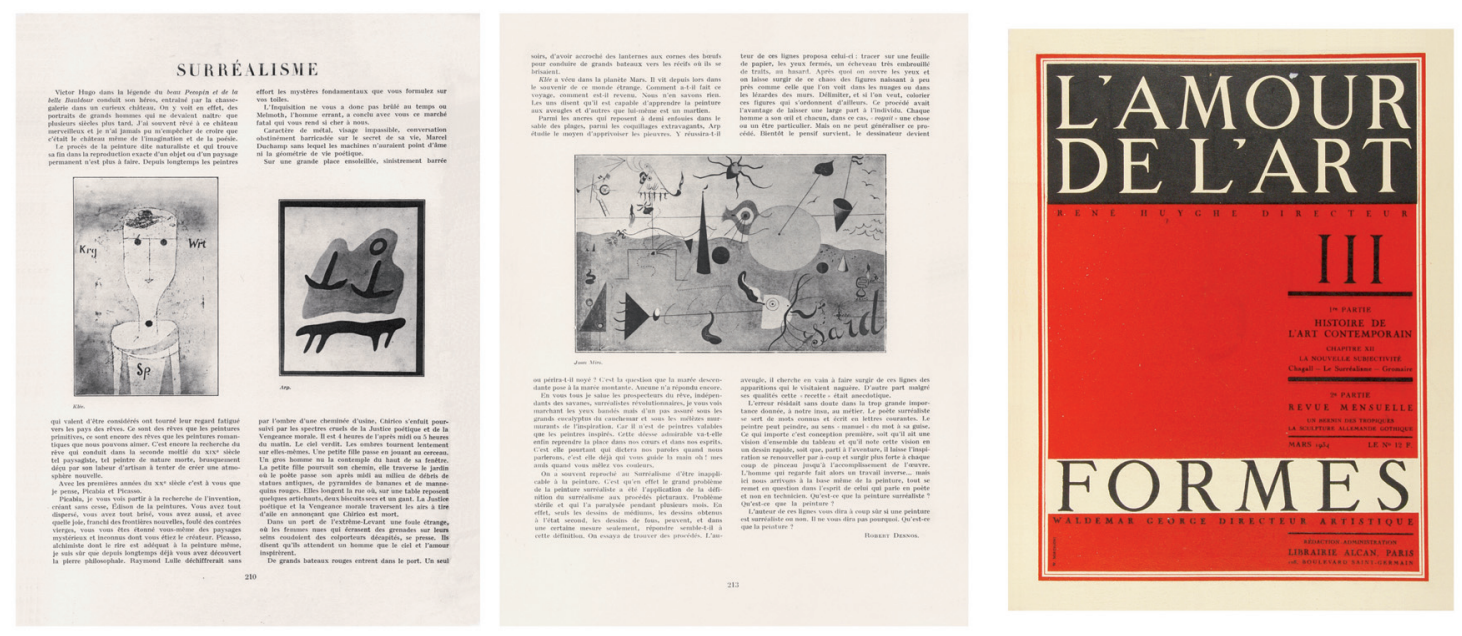

- Fig. 1. El surrealismo en las revistas de arte.- a, b) R. DESNOS,"Surréalisme", Cahiers d'Art, no 8, 1926 (pp. 210-213, 9 ilust): (a) Pág. 210, inicio del artículo. (b) Pág. 213, final del artículo (nota 3); c) L'Amour de l'Art, no 3, 1934: portada del fascículo dedicado al surrealismo (nota 6).
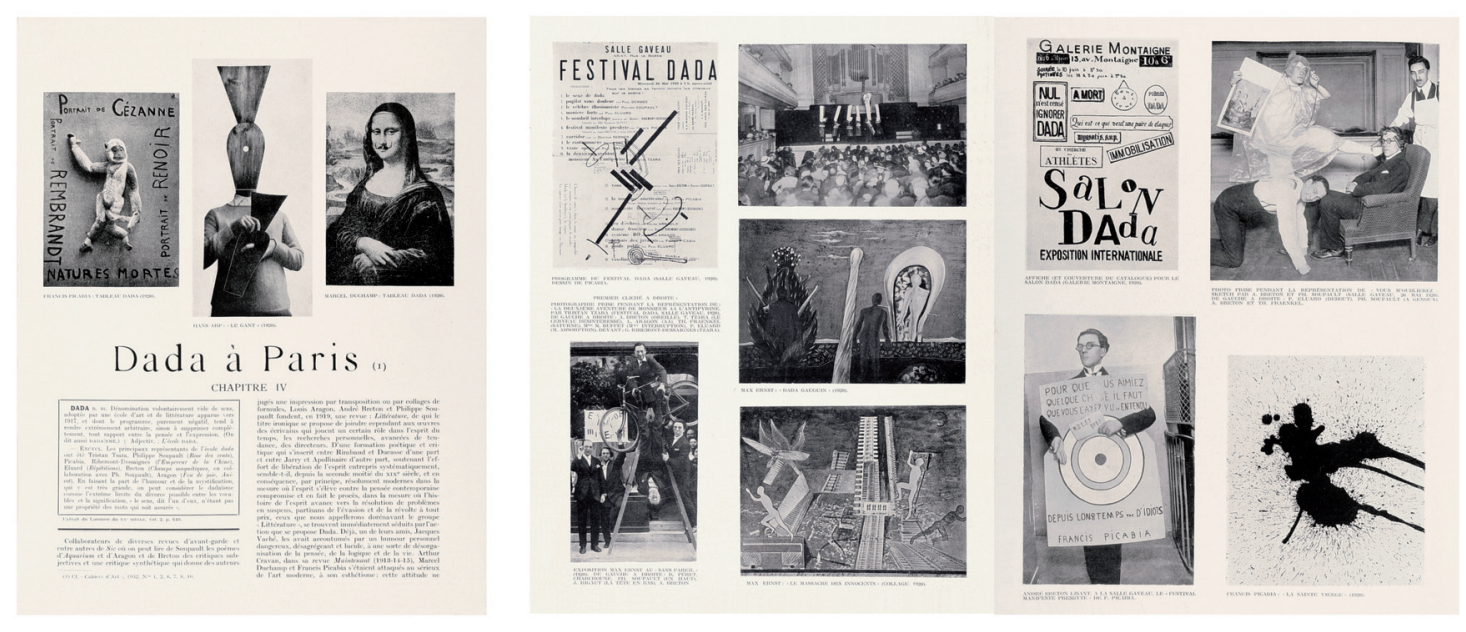

- Fig. 2. Acción Dadá (I).- G. HUGNET, “Dadá à Paris”, Cahiers d'Art, no 1-4, 1934 (pp. 109-114, 12 ilust.): a) Pág. 109, inicio del artículo; b) Pliego siguiente, págs. 110-111: festivales y exposiciones dadaístas con la presencia de quienes conformarán el grupo surrealista. 

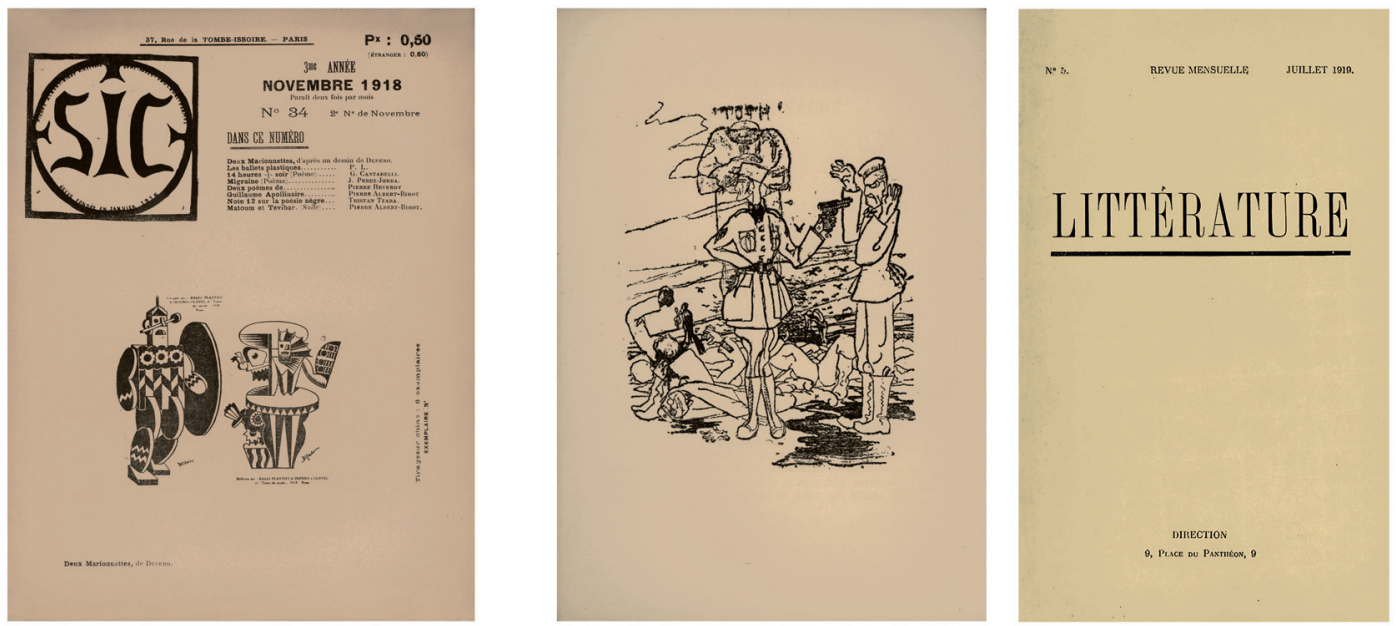

- Fig. 3. Precedentes de Dadá; Littérature.- a) SIC, nº 34, noviembre 1918 (8 págs.): portada de F. Depero (nota 15); b) J. Vaché. Lettres de guerre. Au sans pareil (Coll. de Littérature), París 1919: dibujo de J. Vaché; c) Littérature $1^{\mathrm{a}}$ serie, $\mathrm{n}^{\mathrm{o}}$ 5, julio 1919 (24 págs.): la sobria imagen de la revista (nota 26).
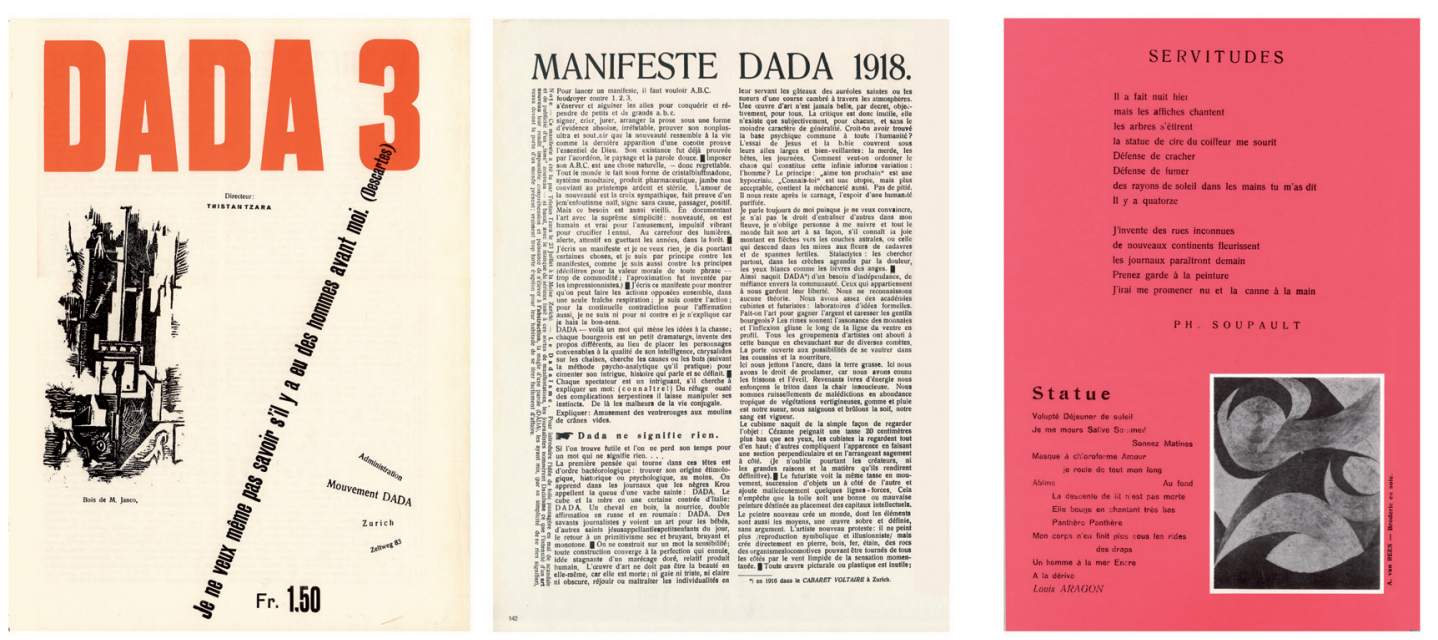

- Fig. 4. Dada de T. Tzara.- a, b) Dada, no 3, Zurich 1918 (16 págs.): (a) Portada. (b) Pág. 2 con el inicio del Manifeste Dada 1918; c) Dada, no 4-5, Zurich 1919 (35 págs.), pág. 14: la participación de los poetas parisinos (nota 24). 

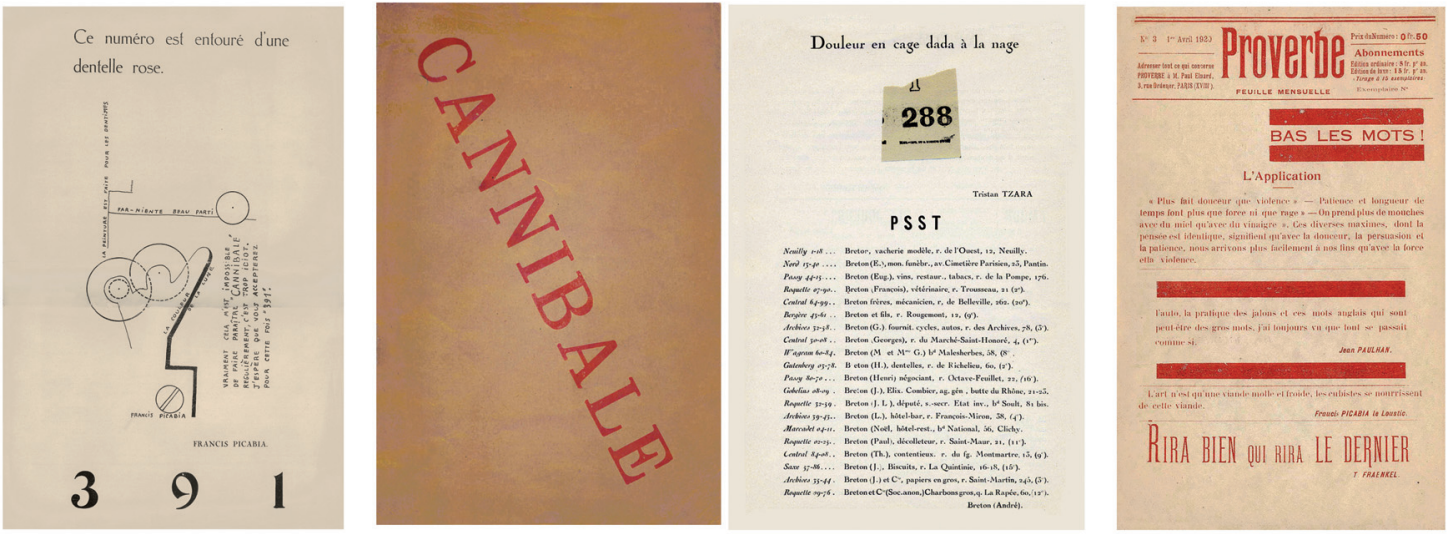

- Fig. 5. Otras revistas del entorno Dadá.- a) 391, nº 13, París, julio 1920 (4 págs.): portada de Picabia (nota 20); b, c) Cannibale, nº 2, París, mayo 1920 (20 págs.): (b) Portada. (c) Pág. 10, con una intervención de Tzara (nota 21); d) Proverbe, no 3, París, abril 1920 (4 págs.): portada (nota 22).
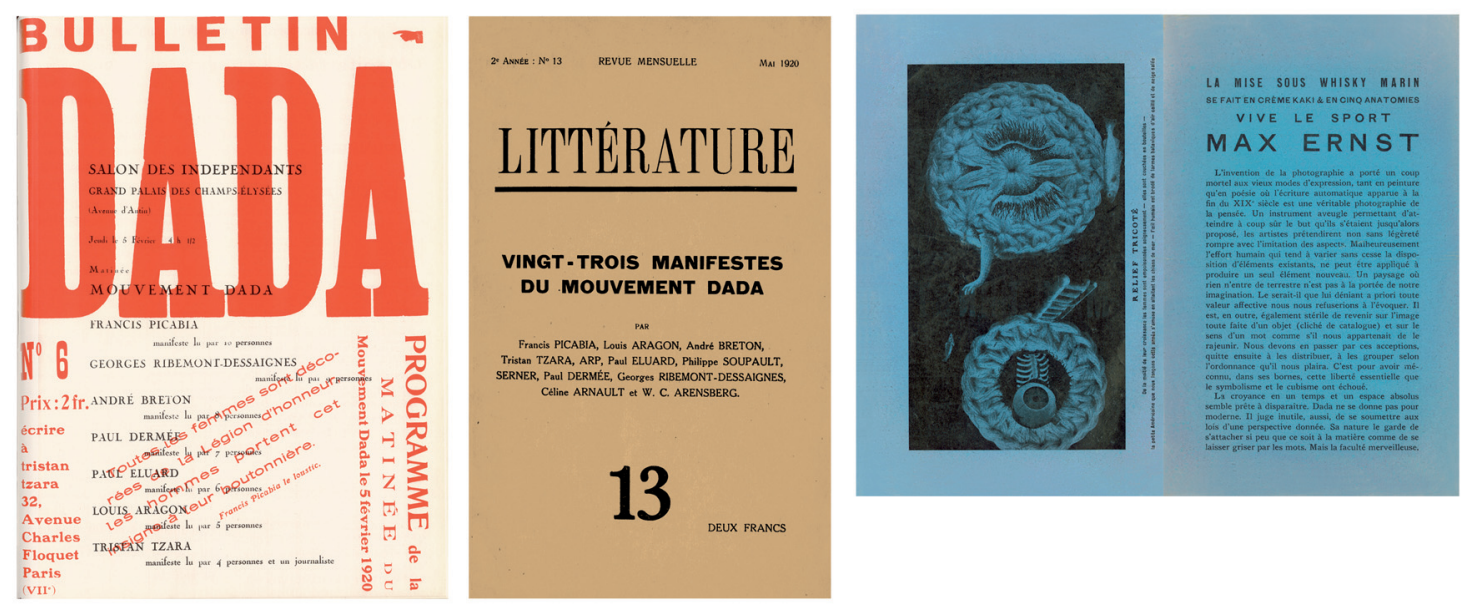

- Fig. 6. Acción Dadá (II).- a) Dada, nº 6, París 1920 (4 págs.): portada con programa de lecturas en el Salon des Independants; b) Littérature, $n^{\circ} 13$, París, mayo 1920: número que contiene los manifiestos leídos; c) Programa de la exposición de M. Ernst en Au sans pareil, 1921(nota 32). La misma imagen apareció en Littérature. 

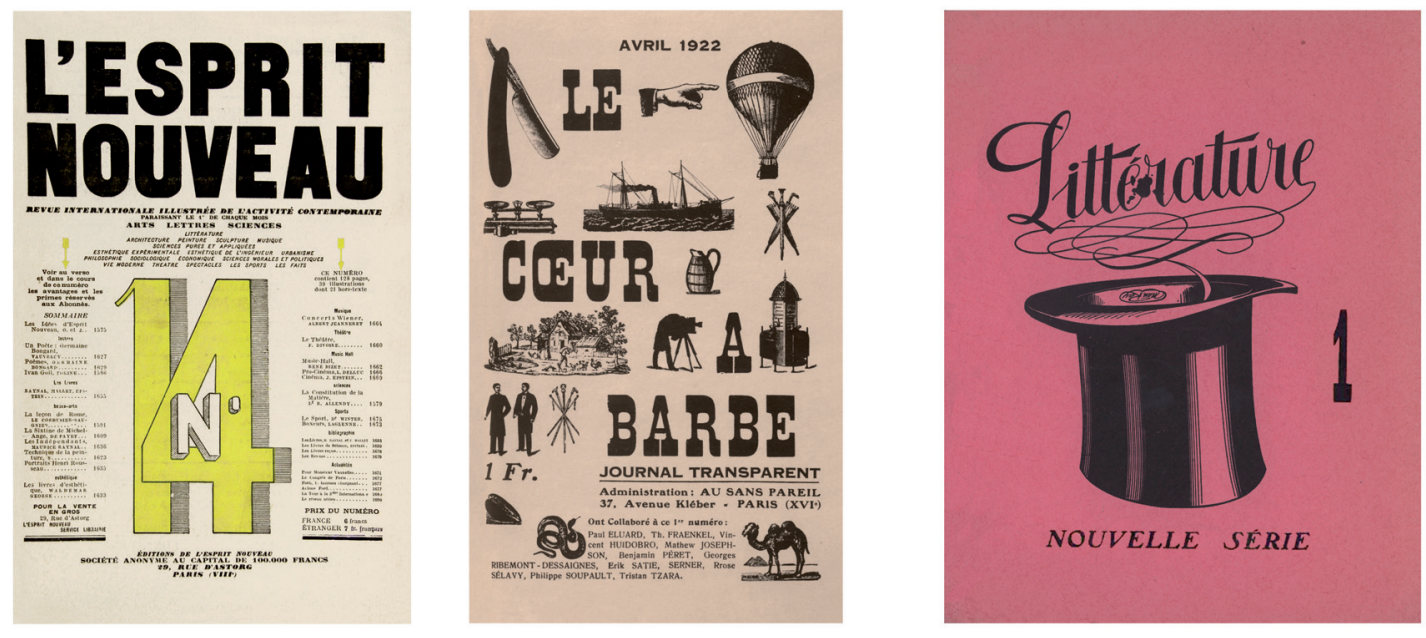

- Fig. 7. El Congrés de Paris.- a) L'Esprit Nouveau, nº 14, París, enero 1922 (nota 40): la convocatoria del Congreso aparece extensamente en la pág. 1672; b) Le coeur à barbe, nº 1, París, abril 1922 (nota 41); c) Littérature $2^{\mathrm{a}}$ serie, $\mathrm{n}^{\mathrm{o}}$ 1, París, marzo 1922 (24 págs., 1 inserto.): portada Chapeau haut-de-forme de Man Ray.
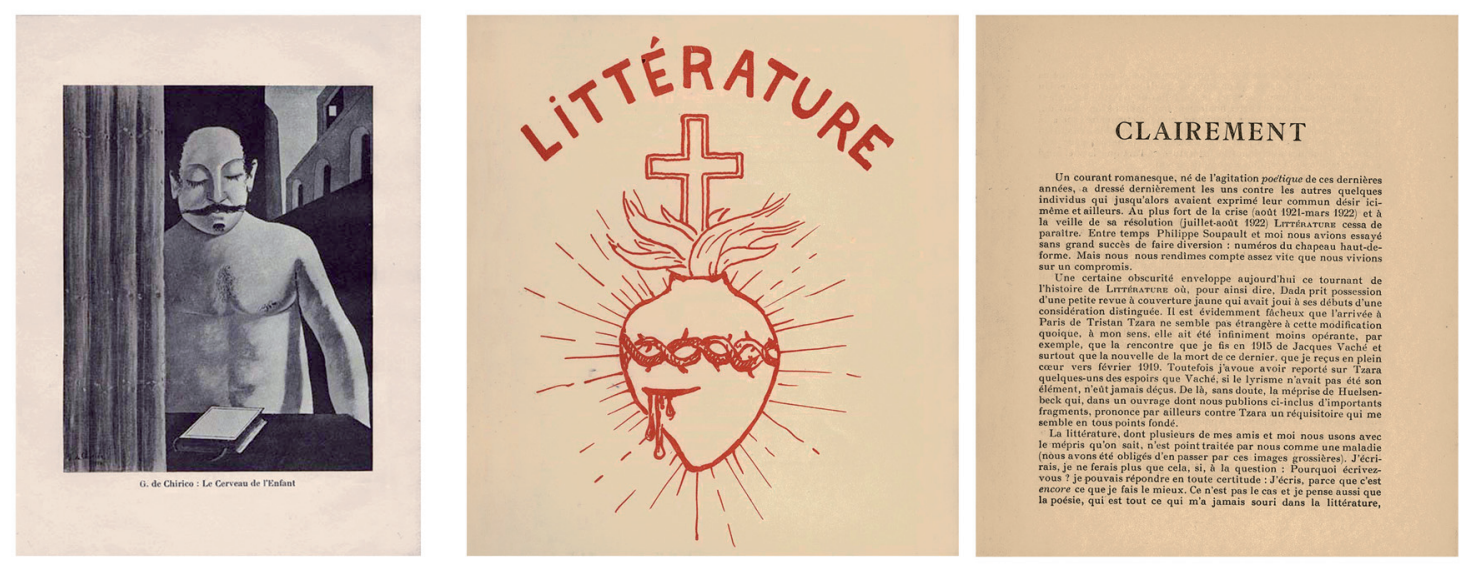

- Fig. 8. Littérature $2^{\mathrm{a}}$ serie (I).- a) Le Cerveau de l'Enfant de G. de Chirico, inserto en el no 1 : el arte en la revista; b, c) no 4, París, septiembre 1922 (32 págs.): (b) Primera portada de Picabia. (c) Pág. 1, inicio de "Claramente" (nota 36). 

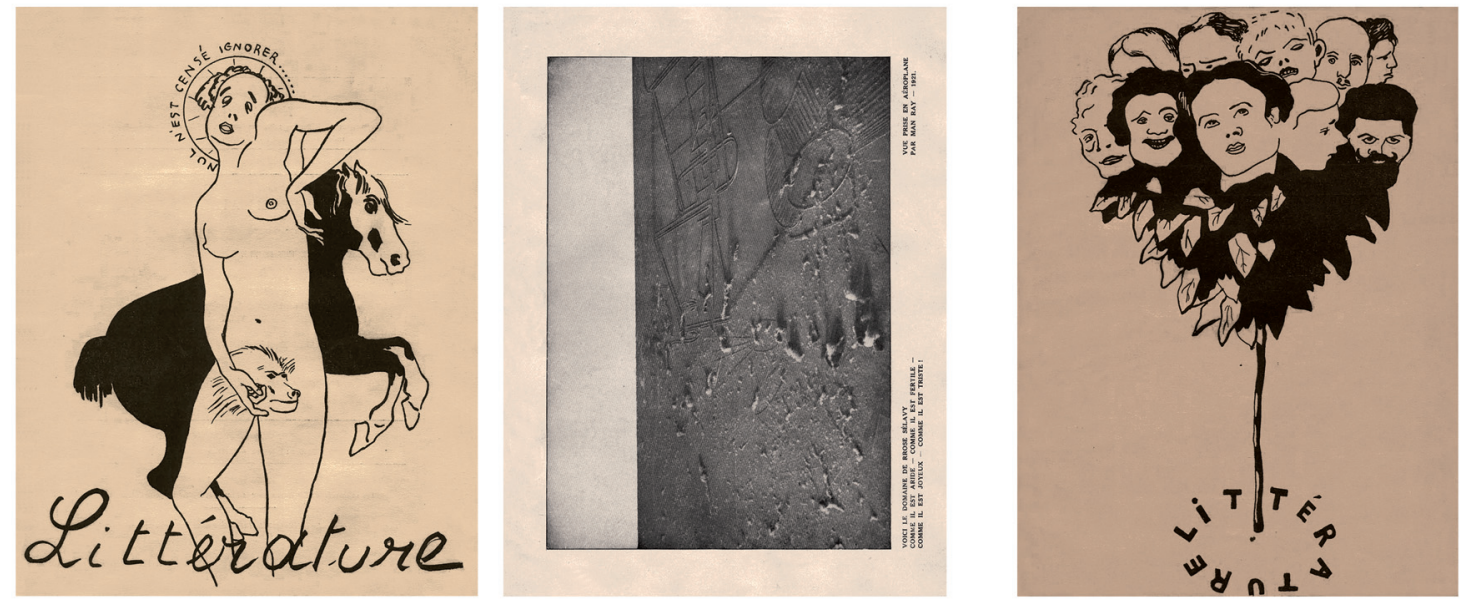

- Fig. 9. Littérature $2^{a}$ serie (II).- a) no 5, París, octubre 1922 (24 págs., 2 insertos.): portada clásica de la $2^{\mathrm{a}}$ serie, dibujo en negro y siempre distinto de F. Picabia; b) Duchamp-Man Ray, inserto en el $\mathrm{n}^{\mathrm{o}} 5$; c) $n^{\circ}$ 8, París, enero 1923 (24 págs., 2 insertos): portada de Picabia con retrato del grupo.
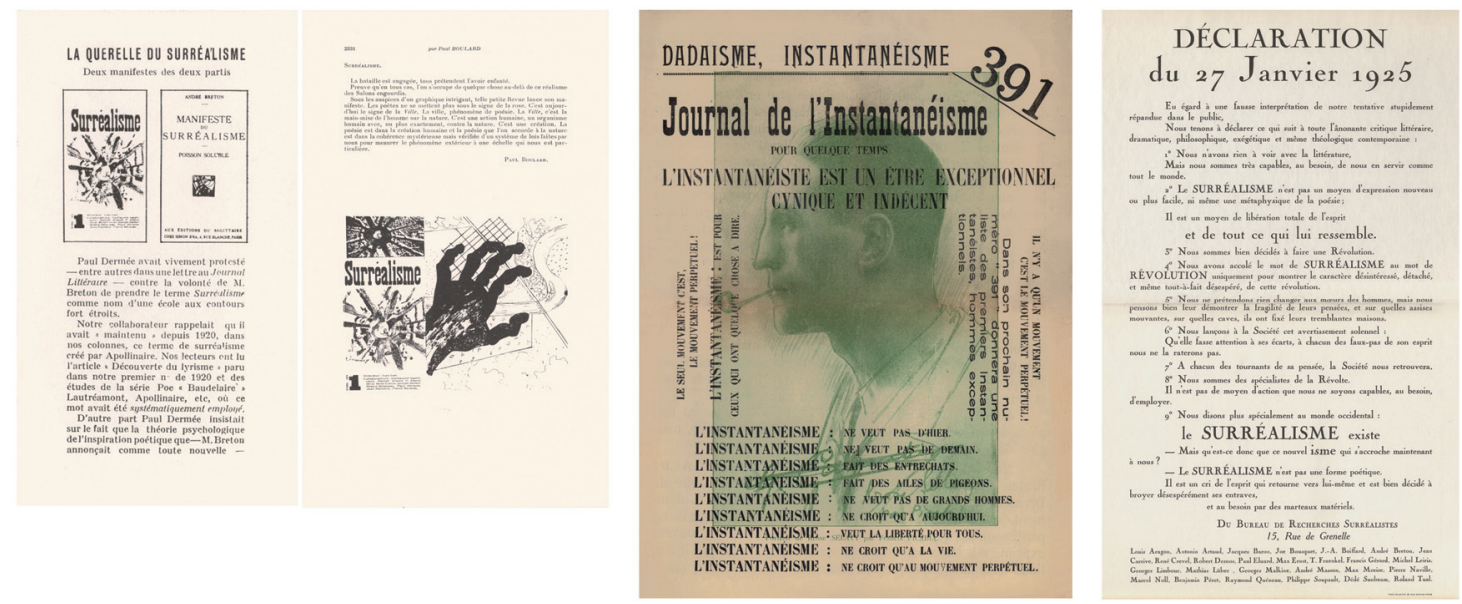

- Fig. 10. Irrupción del surrealismo.- a, b) L’Esprit Nouveau, n 28, enero 1925: (a) Fragmento de la pág. 2324. (b) Pág. 2325. La revista Surréalisme y los conflictos acerca del término “surrealismo” (nota 58); c) 391, n 19, París, noviembre 1924 (4 págs.): última entrega de 391 con la proclama del Instantanéisme (nota 56); d) Panfleto programático del Bureau de recherches surréalistes dirigido por A. Artaud (1925). 

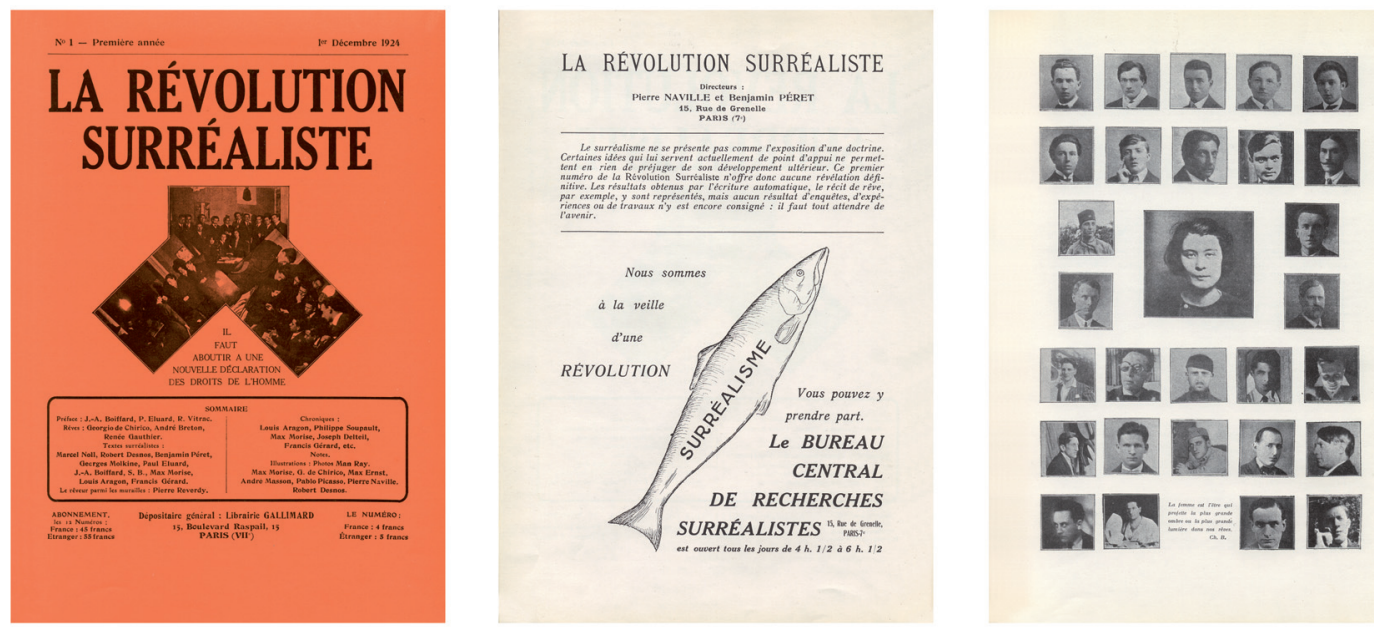

- Fig. 11. Acción surrealista.- La Révolution surréaliste, $n^{\circ}$ 1, diciembre 1924 (nota 64): a) Portada en rojo con montaje de fotografías del grupo surrealista; b) Contraportada primera con declaración y anuncio del Bureau; c) Pág. 17: tabla de miembros y próximos al grupo, alrededor de la activista Germaine Berton.
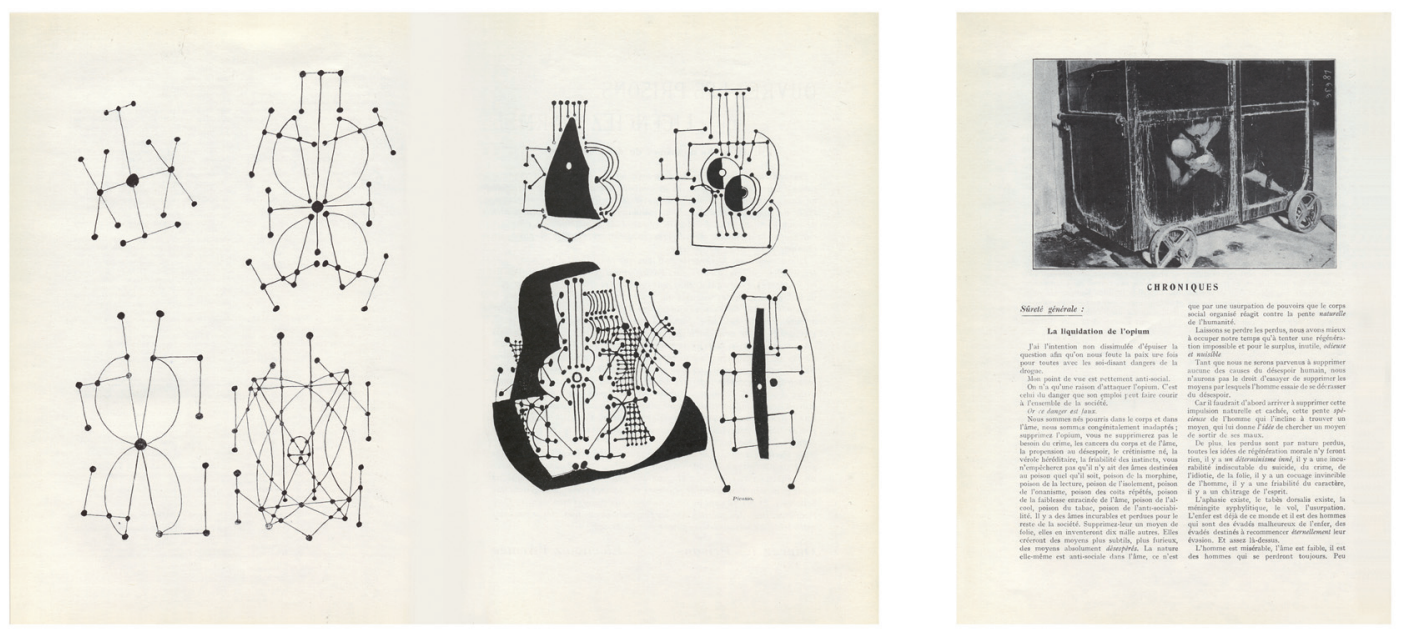

- Fig. 12. La imagen.- La Révolution surréaliste, $n^{\circ}$ 2, enero 1925: a) Pliego págs. 16-17: Picasso: Tintas chinas (tituladas en ocasiones Constellations); b) Pág. 20: desasosegante imagen sin identificación ni comentario asociado, tal como es común en la revista. 

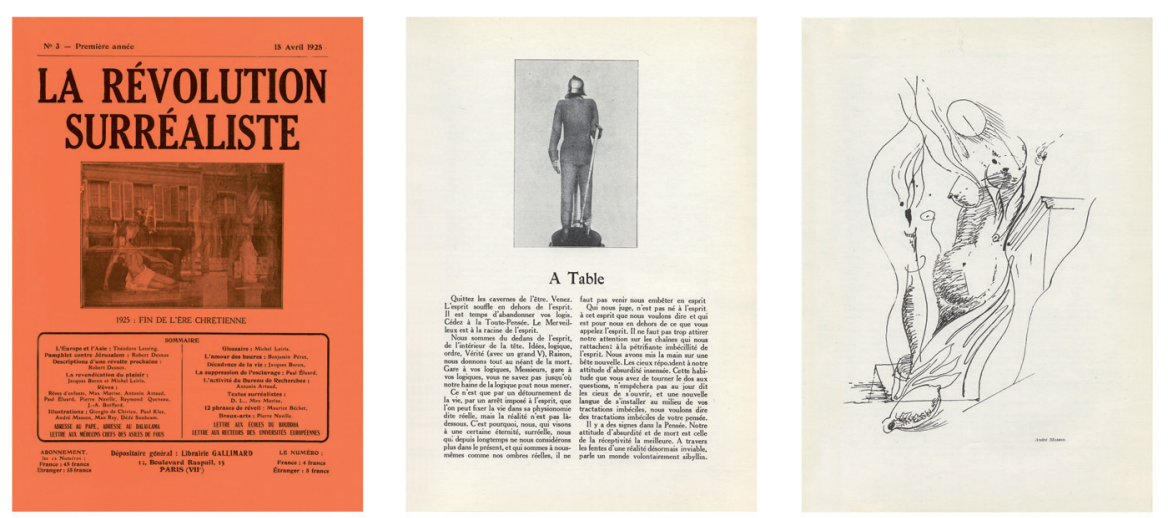

- Fig. 13. Antonin Artaud.- La Révolution surréaliste, no 3, abril 1925: a) Portada: 1925 Fin de la era cristiana; b) Editorial: "A Table”, atribuible a Artaud; c) Pág. 23: dibujo de A. Masson, artista con gran presencia en este número.
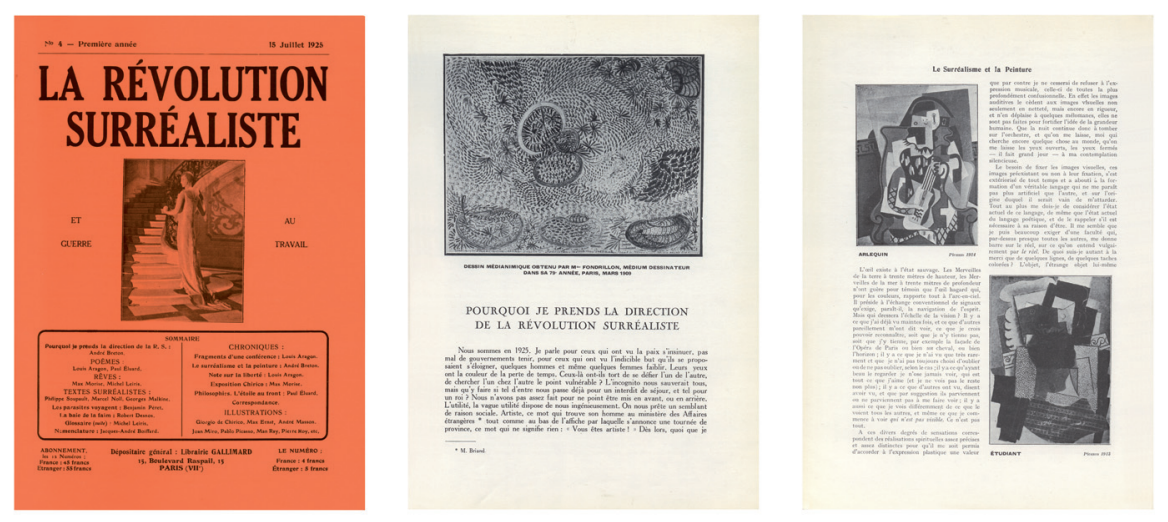

- Fig. 14. Dirección de Breton.- La Révolution surréaliste, no 4, julio 1925: a) Portada: Y guerra al trabajo; b) A. BRETON: "Por qué tomo la dirección de la Revolución surrealista", pág. 1; c) A. BRETON: "El surrealismo y la pintura", inicio de la primera entrega, pág. 16. La gran presencia de Picasso en este número.
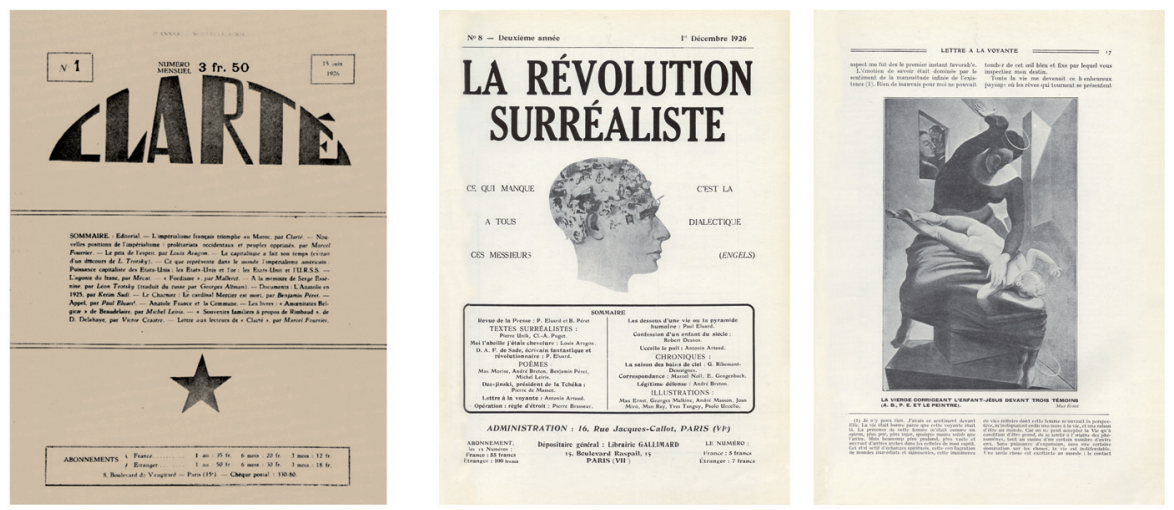

- Fig. 15. Política y poesía.- a) Clarté, París, junio 1926: participación surrealista en esta revista revolucionaria; b, c) La Révolution surréaliste, $\mathrm{n}^{\circ}$ 8, diciembre 1926: (b) Portada: Lo que les falta a todos estos señores es la dialéctica. (Engels). (c) Pág. 17, M. Ernst: La Virgen corrige al niño Jesús ante tres testigos (A. B., P. E., y el pintor). 

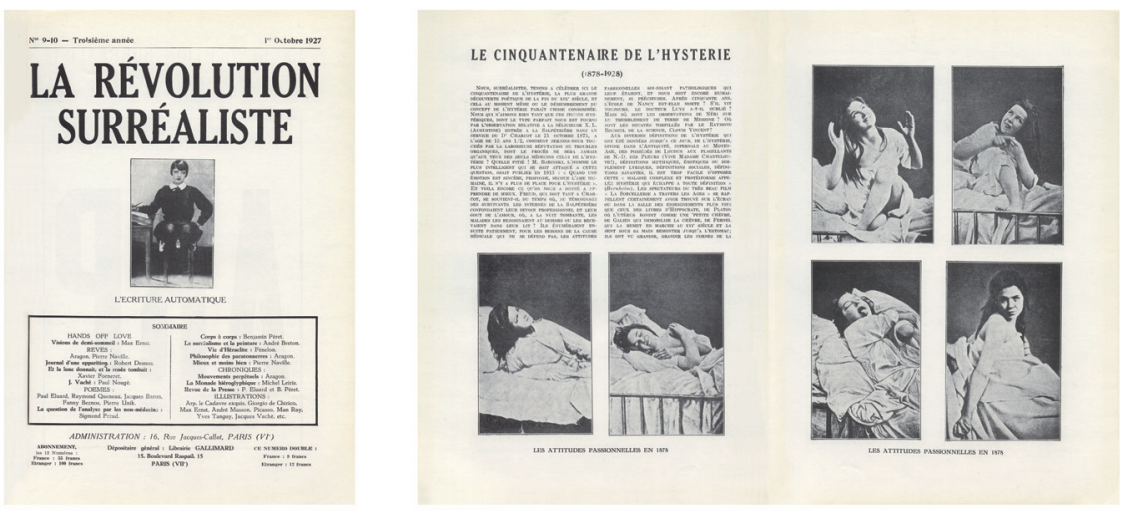

- Fig. 16. Sueño, sexualidad, amor.- a) La Révolution surréaliste, n 9-10, octubre 1927, portada: La escritura automática; b) A. BRETON y L. ARAGON: "El cincuentenario de la histeria (1878-1928)", La Révolution surréaliste, n 11, marzo 1928, pliego págs. 20-21: la histeria como “medio supremo de expresión”.
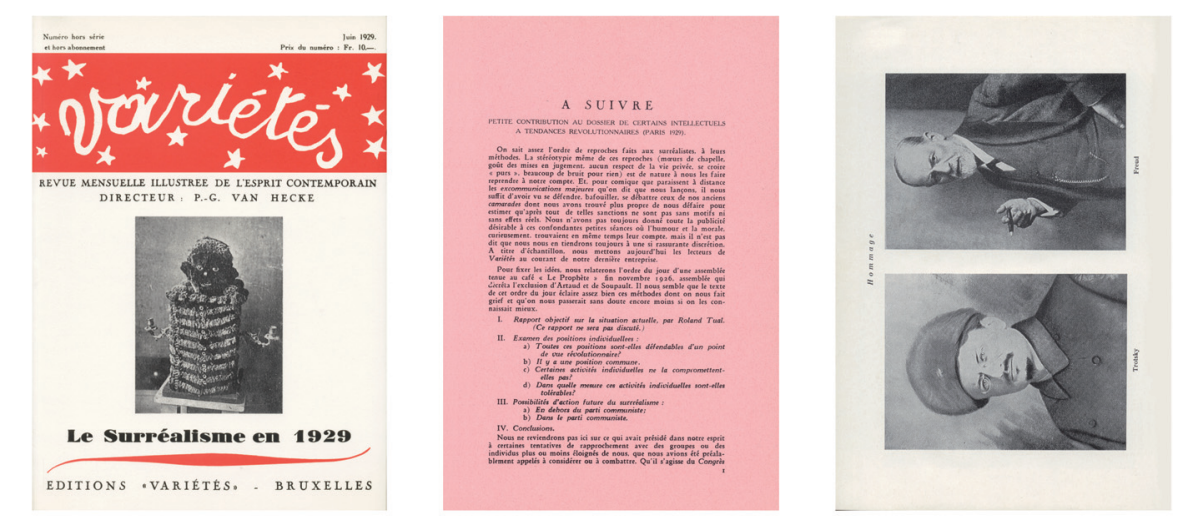

- Fig. 17. El número belga.- Variétés. Le Surréalisme en 1929, Bruselas, junio 1929 (nota 87): a) Portada con orla roja e imagen nunca identificada; b) L. ARAGON y A. BRETON: "Continuará”, pág. i; c) "Homenaje. Trotsky - Freud", $1^{\text {er }}$ cuadernillo de imagen.
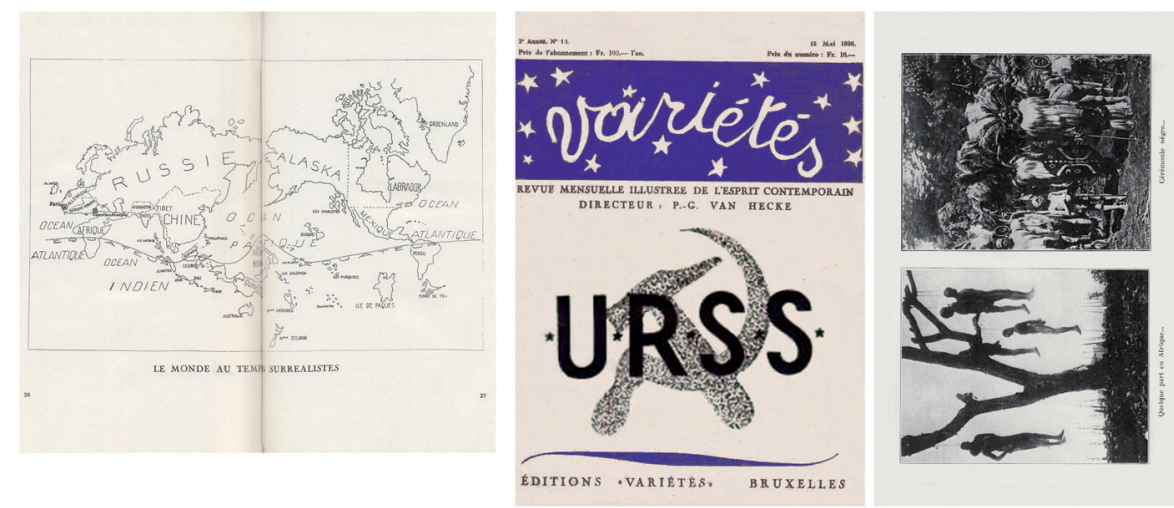

- Fig. 18. Variétés.- a) Le Surréalisme en 1929, pliego págs. 26-27: "El mundo en la época de los surrealistas"; b) Variétés, n 11, mayo 1930: portada clásica del nº especial dedicado a la Unión Soviética; c) Variétés, no 7, noviembre 1928, pág. de imagen: especial dedicado a África: -“Algún lugar en África...” -“Ceremonia negra..." 

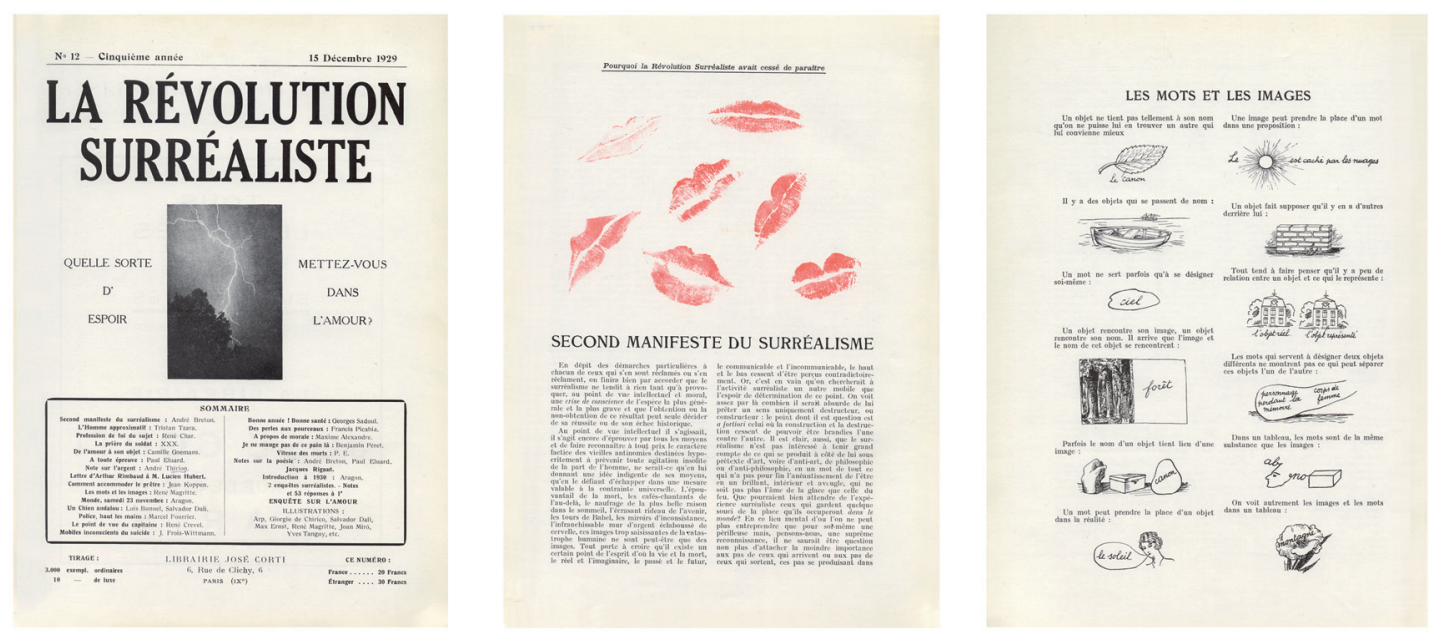

- Fig. 19. Reaparición y final.- La Révolution surréaliste n 12, diciembre 1929: a) Portada: ¿Qué espera usted del amor?; b) A. BRETON: "Segundo manifiesto del surrealismo", pág. 1; c) R. MAGRITTE: "Las palabras y las imágenes", pág. 32.

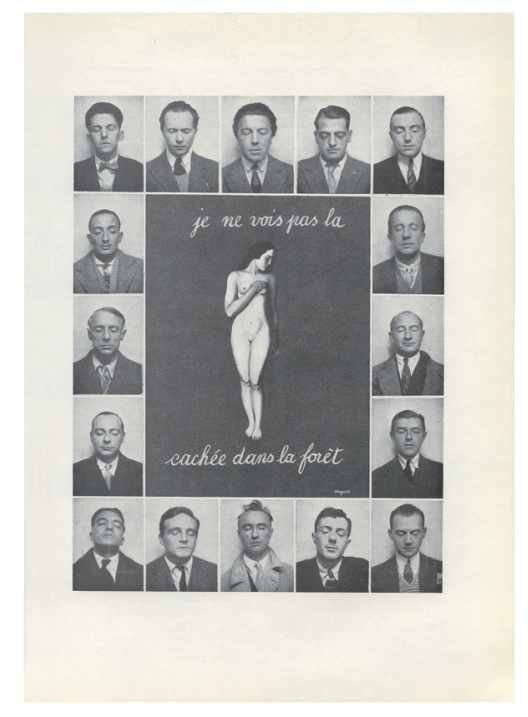

- Fig. 20. "No veo la... oculta en el bosque".- $L a$ Révolution surréaliste, $\mathrm{n}^{\circ} 12$, diciembre 1929, pág. 73: Montaje fotográfico que reúne al grupo surrealista de fines de 1929. En el sentido de lectura: Maxime Alexandre, Louis Aragon, André Breton, Luis Buñuel, Jean Caupenne, Salvador Dalí, Paul Éluard, Max Ernst, Marcel Fourrier, Camille Goemans, René Magritte, Paul Nougé, Georges Sadoul, Yves Tanguy, André Thirion, Albert Valentin. Rodean una pintura de Magritte.
Créditos de imagen:

La totalidad de las imágenes presentadas reproducen portadas o bien páginas, siempre completas, de las revistas aludidas al hilo del texto. Tienen, por ello, carácter de cita respecto a tales documentos.

Las siguientes imágenes han sido tomadas y procesadas por el autor en bibliotecas de investigación (Bibliothèque Kandinsky, París; Bibliothèque de la ENSBA, París; Biblioteca del Ateneo de Madrid; Biblioteca de la Escuela Técnica Superior de Arquitectura de Madrid, UPM; Biblioteca de la Escuela Técnica Superior de Arquitectura de Sevilla, US; Bibliothèque Nationale de France, Paris; y colección personal): Fig. 1; Fig. 2; Fig. 4; Fig. 6 a; Fig. 7; Fig. 8; Fig. 10 a, b, d; Fig. 11; Fig. 12; Fig. 13; Fig. 14; Fig. 15; Fig. 16; Fig. 17; Fig. 18; Fig. 19; Fig. 20. (La Bibliothèque Nationale de France ofrece al dominio publico, página por página, La Révolution surréaliste. En: http:// gallica.bnf.fr/ark:/12148/cb34381250f/date. $\mathrm{r}=\mathrm{LA}+\mathrm{REVOLUTION+SURREALISTE}$.langFR )

Las siguientes imágenes proceden de Digital Dada Library, http://sdrc.lib.uiowa.edu/dada/ index.html (mención: "These documents are provided for research purposes only"): Fig. 3; Fig. 5; Fig. 6 b, c; Fig. 9; Fig. 10 c. 